\title{
Tefsir Usûlü Kavramında Anlam Arayışı
}

\section{Akif YILDIRIM"}

Öz: Bu makalede, ilk dönemden günümüze kadar yazılan Tefsir Usûlü, Ulûmu'l-Kur'ân ve Kavâidü’t-Tefsir literatürü genel olarak taranmış ve bu kavramların anlam ilişkilerinde birlikteliğin olmadığı tespit edilmiştir. Bu sebeple ilgili eserler bağlamında Tefsir Usûlü kavramının anlam ve içerik analizi tekrar yapılmış ve Tefsir Usûlü'nün mâhiyeti belirlenmeye çalışılmıştır. Tefsir Usûlü'nün üst başlık olarak kabul edildiği bu çalışmada, Ulûmu'l-Kư'ân ve Kavâidü’t-Tefsir kavramları alt başlık olarak ele alınmıştır. Bu başlıklandırma esasına dayalı olarak yeni bir Tefsir Usûlü anlayışı teklif edilmiştir. Bu teklif; nihâi bir iddiayı barındırmamakla birlikte ıstılâhî anlam gelişimini tamamlamamış Tefsir Usûlü’ne katkı sunmayı amaçlamaktadır.

Anahtar Kelimeler: Tefsir Usûlü/Usûlü't-Tefsir, Kur'ân İlimleri/Ulûmu'l-Kur'ân, Kavâidü't-Tefsir.

\section{The Search for Meaning in The Methodology of Quranic Exegesis}

Abstract: In this paper, after a general exploration of the literature of Usul al-Tafsir, Ulum al-Quran and Qava'id al-Tafsir from the first period until today, it has been found that there is no consistency in the semantic relations of these concepts. Because of this, the true nature of the concept of Usul al-Tafsir has been determined by its being re-subjected to the semantic and content analysis in the light of the relevant sources. Thusly, in this paper below the general title of the Usul al-Tafsir, the concepts of Ulum al-Quran and Qava'id al-Tafsir were treated in the two following sub-titles. In line with this arrangement, a new understanding of Usul al-Tafsir has been proposed. Without being a final claim, this proposal aims at contributing to Usul al-Tafsir, which itself does not seem to have completed its own semantic development..

Keywords: Usul al-Tafsir, Ulum al-Quran, Qava'id al-Tafsir.

* Bu çalışma, "Muhâsibî, Kâfiyeci ve Subhî Sâlih Örneğinde Tefsir Usûlü ve İçeriği” başlıklı doktora tezimiz esas alınarak hazırlanmıştır

** Arş. Gör. İzmir Kâtip Çelebi Üniversitesi, İslami İlimler Fakültesi, Temel İslam Bilimleri Bölümü, Tefsir Anabilim Dalı. E-Posta: akifyildirim83@gmail.com ORCID ID: https://orcid.org/0000-0003-3609-3440 


\section{Giriş}

İlahi vahye muhatap olan ilk dönem Müslümanları, vahyi kendilerine getiren $\mathrm{Hz}$ Peygamber'le sürekli iletişim halinde olduklarından dolayı Kur'ân'ı anlama noktasında büyük problemler yaşamadılar. Çünkü Hz Peygamber, sahâbenin anlamaya dair yanlış algılarına doğrudan müdahale etmekteydi. Sahâbe için durum böyle iken onlardan sonra gelen nesillerin böyle bir avantajı olmamıştır.

Anlamanın ayrışmaya sebep olduğu ilk olay, Hâricîlerin hakem tayini konusunda Hz Ali'ye karşı isyanıdır. ${ }^{1}$ Hâricilerin² ${ }^{2}$ ortaya çıkışını ve ilk fitnesini her ne kadar $\mathrm{Hz}$ Osman dönemine kadar geri götürenler ${ }^{3}$ olsa da biz onların Sıffın Savaşı'nın akabinde ortaya çıktığı kanaatini taşımaktayız.

İslâm Tarihi'nde anlama noktasında sıkıntı yaşanan bir diğer olay ise Mihne hadisesi olarak bilinmektedir. Mihne hadisesi aslında subjektif anlamanın toplumun tamamına yayılmış acı tezahürüdür. Bu hadisede 'Halku'l-Kurân' meselesi üzerinden ilim ehli başta olmak üzere toplumun bir kısmı imtihandan geçirilmiş ve bu sebeple gerilen ortamda bazı hadis âlimleri katledilirken bazıları hapsedilmiştir. Böylece iktidardaki Mu'tezîlî anlayış, gücünü etkin kılmaya çalışmıştır. ${ }^{4}$ Ancak bu büyük hadiseden önce bizim burada asıl vurgulamak istediğimiz nokta, Kur'ân'ı doğru anlamanın ehemmiyeti ve bu anlama faaliyeti doğru gerçekleşmediği takdirde telâfi edilemez sonuçlara sebep olabildiğidir.

İslâm tarihinde yaşanan bu ve benzeri olaylardan; Kur'ân'ı farklı anlama, yorumlama ve bu anlayış doğrultusunda hayata geçirme eyleminin temelinde insan faktörünün etkili olduğu anlaşılmaktadır. İnsan, öğrendiği ve muhatap olduğu her türlü bilgiyi kendi bilgi ve tecrübe seviyesine göre algılamaktadır. Kelime ve kavramların içine sığdırılmış mânâları, kapasitesi ve edindiği bilgi seviyesine göre anlamaktadır. Nitekim insandaki bu anlama olayı, kavramlara subjektif olarak yüklenen mânâların zihne transfer olmasıyla gerçekleşen bir durumdur. 2018), 147.

2 Hâricîlere göre devlet başkanı 'Emr-i bi'l-Ma'rûf Nehy-i ani'l-Münker' prensibini uygulamakla mükelleftir. Tahkim hadisesinde $\mathrm{Hz}$ Ali de bunu uygulamadığı için ondan ayrılmışlar ve daha sonra da onunla savaşmışlardır. Daha geniş bilgi için bkz: Muhammed b. Yezîd b. Abdilekber b. Umeyr el-Müberred, el-Kâmil fi'l-Edeb, (Beyrut: Müessesetü'r-Risâle, 1986), III, 1077-1079, 11331136; Ethem Ruhi Fığlalı, 'Hâricîler', DiA, (İstanbul: Diyanet Vakfı Yayınları, 1997), XVI, 169-175.

3 Ethem Ruhi Fığlalı, 'Hâricîler', DIA, (İstanbul: Diyanet Vakfı Yayınları, 1997), XVI, 169.

4 Ebi'l-Hasen Ali b. Hüseyin b Ali el-Mes'ûdî, Mürûcu'z-Zeheb ve Meâdini'l-Cevher, (Beyrut: el-Mektebetü'I-Asriyye, 2005), IV, 63; M.Yaşar Kandemir, 'Ahmet b. Nasr el-Huzâi', DiA, (istanbul: Diyanet Vakfı Yayınları, 1989), II, 110. 
İnsanın muhatap olduğu Kur'ân'ın ilahî yönünün olması sebebiyle doğru anlama ulaşmak için metnin mânâsı ile ona muhatap olanın algıladığı anlamın pergel aralığının yakın olması gerekmektedir. Bu şartı yerine getirerek ilahî metne muhatap olan insan, anlam - mânâ ${ }^{5}$ bütünlüğünü sağlayarak murâd-ı ilâhiyi anlamaya daha çok yaklaşacaktır. ${ }^{6}$

Bu süreçte, muhatabın zihnindeki Kur'ân algısının da berrak olması gerekmektedir. Yani Hz Peygamber'in ağzından çıkan ilahi sözlerin, ilgili şartlar altında kayda geçirilerek bizlere tahrif edilmeden ulaştığının muhatap tarafından şüpheye mahal vermeyecek bir şekilde kabul edilmesi gerekir.? Yoksa Kur'ân'ı sıradan bir kitap gibi kabul ederek ona yönelmek, hem algımızın eksikliği sebebiyle anlam noktasında yanılmamıza hem de O'nun mevsûkiyetine halel getirecek düşüncelere kapı aralamamıza sebep olabilmektedir. ${ }^{8}$ Bu sebeple muhatabın Kur'ân'a literal bir metin ${ }^{9}$ olarak yaklaşması gerekir ki ona bu bakış açısını Kur'ân Tarihi bilgileri sunacaktır.

Kur'ân'ı anlama noktasında bireyin metne yaklaşımı yanında toplumsal tavır ve davranışlar da önemlidir. Bu sebeple toplum nezdinde Kur'ân'ı anlama bağlamında yaşanan -yukarıda zikrettiğimiz- ilk kırılmaların ardından hicri ikinci asırda

Bizim burada kullandığımız mânâ ve anlam kavramları ile kastettiğimiz şudur: Mânâ; müellifin veya yazıyı bir araya getirenin kastettiği şeydir. Anlam ise müellifin veya yazıyı bir araya getirenin metnine muhatap olan kimsenin zihninde oluşan şeydir. Bkz: Ibrahim Görener, 'Algılama - Anlama ve Tefsir', Dokuz Eylül Üniversitesi Ilahiyat Fakültesi Dergisi, 17 (2003): 292.

6 Bilginin karşııkı iki kişi arasında aktarılması esnasında bilgiyi aktaran kimsenin jest, mimik, el hareketleri, tonlama ve duraklamalar gibi eylemlerinden dolayı mânâ karşı tarafa daha sağlıklı aktarılma potansiyeline sahiptir. Iletişimde esnasında etkin unsurlar için bkz: Doğan Cüceloğlu, Yeniden Insan Insana, (İstanbul: Remzi Yayınevi, 2000), 68-77.

7 Aslında batının Kur'an'a yaklaşımı ve Kur'an'a metin tenkidi yapmaya çalışmaları da aynı sebepten kaynaklanmaktadır. Çünkü İslâm ve Kur'ân üzerine araştırma yapan oryantalisler; kendi kutsal metinlerini anlamaya çalıştıkları gibi Kur'an metnini anlamaya çalışışlar ve Kur'an'a metin tenkidi yapılması gerektiğini dile getirmişlerdir. Hermönetik yaklaşımın bakış açısını oluşturan metin tenkidi anlayışıyla Kur'ân metnini anlamaya çalışmak, onun mevsûkiyetine halel getirecek bir anlayışla ona yaklaşmayı da içinde barındırabilir. Bkz: Şehmus Demir, Kur'ân'ın Yeniden Yorumlanması, (istanbul: İnsan Yayınları, 2018), 186-188.

8 Bu konuda Kur'ân metnine karşı olumsuz yaklaşımların merkezinde O'nun beşerîliği iddiaları yatmaktadır. Bu iddiaları iki başlık altında toplayacak olursak ilki; Kur'ân'ın indiği dönemin şartlarına bağlı olarak meydana gelmesi sebebiyle beşerîliği, diğeri ise Kur'ân’n içerik olarak dönemin sosyal, kültürel yapıları barındırması sebebiyle beşerîliği. Ayrıntılı bilgi için bkz: Fethi Ahmet Polat, Çağdaş isslâm Düşüncesinde Kur'ân'a Yaklaşımlar, (İstanbul: İz Yayınları, 2018), 253.

9 Biz buradaki literal kavramıla 'metnin anlamına dönük literali'ni değil 'lafzın muhataba kutsiyet inancının kazandııılığı literal'i kastediyoruz. Bkz: Fethi Ahmet Polat, Çağdaş islâm Düşüncesinde Kur'ân'a Yaklaşımlar, 333-338; Osman Eyüpoğlu, Murat Yıldız, 'Kur'ân'ı Anlamaya Yönelik Literal ve Kültürel Yaklaşımların sosyal Değişmeye Uyum Açısından İşlevselliği', Manas Sosyal Araştırmalar Dergisi, 5/3 (2016): 171-173. 
İslâmî ilimlerin tedvîni başlamış ve tefsir ilmi bu çalışmalardan etkilenmiştir. Öncelikle Kur'ân'ın tefsiri hususunda kendisine ihtiyaç duyulmasıyla birlikte lüğavî ilimler tedrici olarak telif edilmeye başlanmıştır. Dönemin İslâm âlimleri, vuku bulan toplumsal ve siyasi değişimler sebebiyle, şer'î hükümler üzerinde gerçekleşmesi muhtemel siyasi ve/veya şahsî tercihleri izale etmeyi amaçlayan ilmî ölçüler koymaya çalışmışlardır. Bunun üzerine nassın beyanını anlamaya yardımcı olan kâideler, ilk olarak Fıkıh Usûlü ilmi içerisinde kendine yer bulmuştur.

Anlamaya yönelik oluşturulan bu kâideler, müfessirlere Kur'ân'ın tefsiri hususunda yorum kapısını aralamış ve ictihatlarını ortaya koymalarına olanak sağlamıştır. Bu alanda İmam-ı Şafiî́nin (ö. 204/820) er-Risâle'si, Kur'ân'ı usûlî bir anlayışa göre yorumlamaya yardım eden ilk çalışmalardan sayılmaktadır.

Kur'ân'ı anlamaya dönük yapılan kural belirleme/kâideleştirme çalışmalarında müellifler, bu faaliyetlerini ilk dönemden itibaren ilmî bir zemine oturtmaya çaıışmışlardır. Illk dönemde Fıkıh ilmiyle gelişen bu yaklaşım tarzı, daha sonra Tefsir ilminde de kendine yer bulmuştur. Özellikle müfessirler bu alanda yazdıkları eserlerin bir bölümünde re'y ile tefsirin kurallarını ortaya koymaya çalışmışlar; akılla taaruz ettiği zannedilen bazı âyetlerin nasıl anlaşılması gerektiği hususuna da değinmişlerdir.

Fıkıh Usûlü, Hadis ve Akâid ilminin gelişmesiyle birlikte müfessirler, diğer ilimlerden bağımsız Tefsir ilmine has ilke ve kural ortaya koyma ihtiyacı hissetmişlerdir. Bu durumda uygulamalı bir ilim olan Tefsir ilminin kendisine ait teori ve kâidelerini belirleme çalışmaları başlamıştır. Tefsîr ilminde Kavâid literatürü olarak değerlendirdiğimiz bu yaklaşım, önce fıkıh alanında 'Elfâz ve Delâlet' bahisleri şeklinde ortaya çıkmıştır.

Ulûmu'l-Kur'ân adını taşıyan müfessirin ihtiyaç duyduğu bilgiler manzumesi ise ilk dönemlerde yazılı olarak kaydedilmese de anlam ve içerik olarak neye tekabül ettiği ilim ehli arasında bilinmekteydi. Bunun en güzel örnekliğini Haliffe Harun Reşit (ö. 193/809) ile İmam-ı Şafiî arasında geçen diyalog ${ }^{10}$ bize sunmaktadır. ye mezhebinin başı olmakla itham edilmis ve bu sebeple Hârûn Reşîd'in huzuruna çıkarılmıştır. Hârûn Reşîd İmam Şâfii'ye Allah'ın Kitab'ı hakkındaki ilmini sorunca İmam Şâfî, Allah'ın kitaplarından hangisini sorduğunu ve Allah'ın çok sayıda kitap indirdiğini söyler. Hârûn Reşîd'in Kur'ân'ı kastettiğini söylemesi üzerine İmam Şâfiî şöyle der: 'Kur'ân ilimleri (Ulûmu'l-Kur'ân) çoktur. Sen bana onun muhkemini mi müteşâbihini mi, takdimini mi ve tehirini mi, nâsihini mi 
Kur'ân Tarihi'ni de kapsayan Ulûmu'l-Kur'ân konuları, tarihî süreçte derlenerek nakledilmiş ve bu konuda muhtelif eserler te'lif edilmiştir. Bu alanda yapılan çaIışmaların artması ve te'lif edilen tefsirlerin mukaddimelerinde ele alınan konuların belli bir birikime ulaşmasıyla Tefsir Tarihi'ne dair bilgiler oluşmuş ve Tefsir ilminin müktesebatı şekillenmeye başlamıştır.

Ulûmu'l-Kur'ân kavramının ortaya çıkmasıyla ilerleyen zamanlarda Tefsir ilminde bazı kavramsal gelişmeler yaşanmıştır. Özellikle hicrî VIII.ve IX. asırda Tefsir Usûlü yeni bir kavram olarak çıkmış ${ }^{11}$ ve Kur'ân'ı anlamaya yönelik yaklaşımların merkezine oturmuştur. Tefsir Usûlü teriminin yanında anlamaya dair yaklaşımların ortaya koyduğu bir diğer terim ise Kavâidü't-Tefsir'dir.

Bu çerçevede çalışmamızın yapısını oluşturan terimler; Usûlü't-Tefsir, Ulûmu'l-Kur'ân ve Kavâidü't-Tefsir kavramlarıdır.

\section{Kavramsal Çerçeve}

\subsection{Tefsir Usûlü/Usûlü't-Tefsir}

Vahiy karşısında yukarıda temas ettiğimiz türden bilgilere karşı tutumumuzu belirleyen en önemli kavram Tefsir Usûlü'dür. 'Usûlü't-Tefsir' veya 'Tefsir Usûlü' terkibi, 'usûl' ve 'tefsir' kavramlarının bir araya gelmesiyle oluşmuştur. Bu terkipte yer alan 'tefsir' kelimesi, konumuzla ilgili bir kavram olmasıyla birlikte çalışmamızda vurguladığımız ve olaya farklı bir bakış açısı getirdiğimiz asıl kavram 'usûl' kavramıdır. Bu sebeple tefsir' ${ }^{12}$ kelimesi hakkında yapılan tartışmalara ${ }^{13}$ gir-

mensûhunu mu soruyorsun?'. İlgili diyalog için bkz: Muhammed Abdülazîm ez-Zürkânî, Menâhilü'l-İrfân fí Ulûmi'l-Kur'ân, (Beyrut: Dâru'l-Kütübi'l-Illmiyye, 2013) I, 25; Subhi Salih, Mebâhis fî Ulûmi'l-Kur'ân, (Şam: Matbaatu'l-Câmiatü's-Suriyye, 1958), 123-124.

11 İbn Teymiyye'nin Tefsir Usûlü kavramını kullanan ilk müellif olduğu konusunda bkz: Ömer Çelik, 'Hicrî V-XI Asırlarda Kur'ân İlimleri', Kur'ân ve Tefsir Araştırmları-III, (İstanbul: Ensar Yayınları, 2002), 52.

12 Tefsir kavramının anlamı için bkz: Halil b. Ahmed el-Ferâhidî Kitabü'l-Ayn, (Beyrut: Dâr-u İhyâi't-Türâsi'l-Arabî, 2005), 430-431, 743; Ebu'l-Hüseyn Ahmed b. Fâris, Mu'cemu Mekâyîsü'l-Lüğa, (Beyrut: Dâr-u İhyâi't-Türâsi'l-Arabî, 2008), 462, 818; İsmail b. Hammad el-Cevheri, es-Sıhah Tacu'l-Luğa ve Sıhahı'I-Arabiyye, (Beyrut: Dâru'I-Ilmi li'I-Melâyîn, 1990), II, 781; Ebu Mansur Muhammed b. Ahmed el-Ezheri, Tehzibü'l-Luğa, (Kahire: ed-Daru'l-Mısrıyye li't-Te'lif ve't-Terceme, Tsz), XII, 406-407; Ebu'l-Fadl Cemaleddin Muhammed b. Mükerrem b. Manzûr, Lisânü'l-Arab, (Beyrut: Dâr-u Sâdır, 1967), V, 55; Seyyid Muhammed Murtazâ el-Hüseynî ez-Zebîdî, Tâcu'l-Arûs min Cevâhiri'I-Kâmûs, (Kuveyt: Matbaat-u Hükûmet-i Kuveyt, 1974), XIII, 223-224.

13 Tefsir kavramının hangi kökten geldiği, hangi manalara tekabül ettiği, Kur'ân-ı Kerim’de hangi anlamlarda kullanıldığı, te'vil kavramı ile olan anlam ilişkisinin ne olduğu gibi konular bağla- 
meden usûl kavramını ve bu iki kelimenin terkibiyle oluşan Tefsir Usûlü kavramını ele alacağız.

\subsubsection{Usûl Kavramının Sözlük ve Istılahî Anlamı}

Köken olarak Arapça olan 'Usûl' (اصول) kelimesi 'Asl' (اصل) kelimesinin çoğuludur. ${ }^{14}$ 'Usûl' kelimesi sözlükte; 'Bütün nesnelerin alt/aşağı (اسفل) kısmı ${ }^{15}$, üzerine başka şeylerin bina edildiği şey ${ }^{16}$, kendisinin ihtiyaç duymadığı ancak kendisine ihtiyaç duyulan şey ${ }^{17}$, nesnelerin (şeylerin) temeli/kökü ${ }^{18 \prime}$ manalarına gelmektedir. Bu kelime, farklı sözcük grupları ile kullanıldığında ise; 'Birleşip kök salmak veya bir şeyi kökünden sökerek yok etmek ${ }^{19}$, herhangi bir sebepten dolayı tadı ve kokusu değişen $\mathrm{su}^{20 \prime}$ anlamlarına da gelmektedir.

Usûl kelimesi ile aynı kökten türeyen ve diğer iştikaklarına göre daha çok kullanılan 'Asîl' (اصيل) kelimesi; 'Ikindi ve akşam arasındaki zaman dilimi'11', 'Asîle' (اصيلة) kelimesi ise 'Helâk, ölüm' anlamlarına gelmektedir. 22 'Asîl' kelimesi 'Re'y' (الراي) limesi ile birlikte (اصيل الراي) şeklinde kullanıldığında ise 'mantıklı ve tutarlı düşünce'yi ifade etmektedir. ${ }^{23}$

mında ele alınan bu tartışmalar, çalışmamızda vurgulamak istediğimiz konuyu dağıtacağından bu kavrama değinmeyeceğiz. Çalışmamızda bu kavrama yer vermememizin bir diğer nedeni ise bu alanda yapılmış çalışmaların çokluğu ve kavramla ilgili yapılan tariflerde tekrara düşmenin kaçınılmaz oluşudur. Çünkü sadece'... Tefsir Usûlü Açısından...' başlığıyla yapılan çalışmalar, eserimiz de dâhil olmak üzere yirmi dokuz tanedir (28.11.2019 tarihi itibariyle). Bunların on bir tanesi doktora tezi, on sekiz tanesi ise yüksek lisans tezi olarak hazırlanmıştır. Biz burada konuya örnek olması bağlamında kavramla ilgili en kapsamlı çalışmayı kaynak vererek geçeceğiz. Bkz: Mehmet Demirci, "Kurtubî́nin El-Cami' li Ahkâmi'l-Kur'ân Adlı Eserinin Tefsir Usûlü Açısından Değerlendirilmesi" (Doktora Tezi, Erciyes Üniversitesi, 2009), 10-50. İbn Manzûr, Lisânü'l-Arab, XI, 16; Ali b. Muhammed b. Ali Cürcânî, et-Ta'rîfât, (Dâru'd-Diyane li'tTürâs, Tsz), 45; ez-Zebîdî, Tâcu'l-Arûs, XXVII, 447. Halil b. Ahmed, Kitabü'l-Ayn, 29; el-Cevheri, es-Sıhah, IV, 1623; İbn Manzûr, Lisânü'l-Arab, XI, 16; ez-Zebîdî, Tâcu'l-Arûs, XXVII, 448. ez-Zebîdî, Tâcu'l-Arûs, XXVII, 448; Muhaammed Ali et-Tehânevî, Keşşâf-u Istılâhâti'l-fünûn ve'lUlûm, (Lübnan: Mektebet-ü Lübnan, 1996), I, 213. Cürcânî, et-Ta'rîfât, s.45; et-Tehânevî, Keşşâf-u Istılâhâti'l-Fünûn, I, 213. İbn Fâris, Mu'cemu Mekâyîsü'l-Lüğa, 62. İbn Manzûr, Lisânü'l-Arab, XI, 16. ez-Zebîdî, Tâcu'l-Arûs, XXVII, 451. el-Cevheri, es-Sıhah, IV, 1623; ez-Zebîdî, Tâcu'I-Arûs, XXVII, 448-449. İbn Manzûr, Lisânü'l-Arab, XI, 16. 
Konuya dair görüş beyan eden Ebû Hilal el-Askerî'ye (ö. 400/1010) göre 'asl' kelimesi, müşterek anlam ifade eden bir isimdir. Ona göre 'Asl'; 'mevcut olan şeyin aslının hakikati ve kendisiyle başlanılan şey'dir. ${ }^{24}$ Râgıp el-Isfahânî'ye göre 'Asl' kelimesinin karşılığı ise 'bir şeyin, üzerine oturduğu kâidesi'dir'.25

Arap dilinde 'asıl, kök, temel, esas' olarak tarif edilen usûl kavramı, Türkçe'de genellikle 'metot' kelimesiyle karşılık bulmuştur. Ancak Türkçe sözlüklerde yer alan tanımlarda, ıstılahî anlamın ağırlıkta olduğu görülmektedir. ${ }^{26}$

Türk diline Yunanca veya Fransızca'dan girdiği kabul edilen²7 'Metot' kelimesi, Tefsir Usûlü kavramını tarif ederken karşılaştığımız kelimelerin başında gelmektedir. Türkçe'de 'amaca ulaşabilmek için bir şeyi bazı temel ilkelere uygun olarak yapma biçimi, yöntem, usûl' olarak tarif edilen 28 'metot' kelimesi, Yunanca'da 'yol, yol boyunca' anlamlarına karşılık gelmektedir. ${ }^{29}$

'Metot' kelimesi ile bu kelimeden türetilen 'metodoloji'30 kelimesi arasında ise bir fark bulunmaktadır. Bu konuda görüş bildiren İbrahim Görener'e göre 'metot' kavramı, uygulanabilirlik açısından doğrudan somut veya soyut bir nesneye ihtiyaç duymakta metodolojinin ise bir nesneye ihtiyacı bulunmamaktadır. 'Metolodoji'nin nesne ile doğrudan bir irtibatının olmaması nesne ile hiçbir şekilde irtibatının olmadığı anlamına da gelmemektedir. Nitekim metodoloji; nesneyi incelemede bir yöntem olan 'metot'u kendisine konu edinmekte ve 'metot'ta olması gereken şartları ortaya koymaya çalışmaktadır. ${ }^{31}$

Tüm bilimlerde öznel olsun nesnel olsun mutlaka bir metodun varlığından bahsedilir. Her biri ayrı bir özelliğe ve öznelliğe sahip olan sanatsal ürün ve sonuçlar geçen 'asıl' hakikat anlamında, 'seninle falan kimsenin arasındaki düşmanlığın aslı' cümlesinde geçen asıl kelimesi ise mecaz anlamı ifade etmektedir. Ayrıntılı bilgi için bkz: Ebû Hilal el-Askerî, el-Furûku'I-Lüğaviyye, (Kahire: Dâru'I-Ilm ve's-Sekâfe, 1997), 162.

25 Râgıb el-Isfahânî, el-Müfredât, (Dimeşk: Dâru'I-Kalem, 2014), 78-79.

26 Ferit Develioğlu, Osmanlıca-Türkçe Ansiklopedik Lûgat, (Ankara: Aydın Yayınları, 2011), 49, 1308; Yaşar Çağbayır, Ötüken Türkçe Sözlük, (İstanbul: Ötüken Yayınları, 2007), I, 320; V, 5000; Şemseddin Sâmî, Kâmûs-i Türkî, (İstanbul: Ikdâm Matbaası, h.1317), 124.

Türkçe'deki 'Metot' kelimesinin kökeni Yunanca 'Methodos' veya Fransızca 'Methode' kelimeleri olarak kabul edilir. Bkz: Yaşar Çağbayır, Ötüken Türkçe Sözlük, III, 3176.

28 Yaşar Çağbayır, Ötüken Türkçe Sözlük, III, 3176.

29 İbrahim Görener, Tefsir ve Tefsir Usûlü Üzerine Düşünceler, (Kayseri: Laçin Yayınları, 2004), 19.

30 Metodoloji kelimesi sözlükte; 'illimlerin metotlarını araştırıp yeni metotlar ortaya koymak için mantıkî prensipler geliştiren yöntem bilimi, bilimler mantığı' anlamına gelmektedir. Bkz: Yaşar Çağbayır, Ötüken Türkçe Sözlük, IV, 3176.

31 İbrahim Görener, Tefsir ve Tefsir Usûlü Üzerine Düşünceler, 20-21. 
bile takip edilen bir metodun ürünüdür. Bundan dolayı metot hakkında olumlu veya olumsuz bir kanaatten söz edilemez. Çünkü metot; doğruyu elde etmek değil ancak amaca giden yolun şeklini belirlemektir. ${ }^{32}$ Ve her yolda, o yolun kendi kuralları ve metotları ile yürünmelidir. Şunu da belirtmemiz gerekir ki; bir metot için ortaya konan amaç ve gayenin ilmî altyapısından bahsedecek olursak, bu metodun rastgeleliğe sebep olmaması ve genel kabul noktasında asgarî müşterekleri karşılaması gerekmektedir.

Bu bilgiler ışığında metodolojik araştırmaları göz önünde bulundurduğumuzda bir çalışma; belirli bir problem merkezinde ve aynı kaynaklar üzerinde yapılabilmekte ancak yapılan bu çalışmada farklı sonuçlar elde edilebilmektedir. İşte ulaşılan bu farklı sonuçların altında kişinin konu ve probleme yönelik farklı yakIaşımları yatmaktadır. Özellikle Sosyal Bilimler'de bu şekilde ulaşılan sonuçların, araştırmayı yapan kişinin kişisel donanımlarıyla farklı olarak şekillendiği bir başka deyişle öznellik taşıdığı da yadsınamaz bir gerçektir.

İslâm âlimleri, ulaşılan sonuçlardaki bu öznelliğin azalması ve tutarlı düşünce sisteminin oluşması için bazı önerilerde bulunmuşlardır. Ancak öneriler her alanda kabul görmeyince ilimlerin tamamı tarafından benimsenen bazı şartlara ve sistemli düşünce yapısına ihtiyaç duyulmuştur. ${ }^{33}$ Öncelikle Kelam ve Felsefe gibi alanlarda kabul gören Mantık ilminin anlayışı zamanla tüm ilimlere yayılmıştır. Bu sebeple İslâmî ilimlerin ilim ve disiplinleri içerisinde değerlendirilen Mantık ilminin kriterleri, o ilimlerin oluşum ve gelişim süreçlerine dâhil olmuştur.

Mantık ilmini bütün ilimlerin ölçüsü olarak kabul eden Gazzâlî (ö. 505/1111), eseri el-Mustasfâ'nın giriş bölümünde usûlün nasıl olması gerektiğini maddeler halinde sıralamış, 'sonuç elde etme' ve 'müctehidin hallerini bilme'yi de bunlara eklemiştir ${ }^{34}$. Gazzâlî́nin genellikle Fıkıh Usûlü bağlamında ele aldığı usûl kavramı, nispet edildiği ilim dalına göre farklı anlamlar kazanmıştır. Bu sebeple usûl kavramının; Fıkıh, Hadis, Kelâm ve Tasavvuf gibi ilim dallarının her birinde kazandığı anlam diğer ilim dalında aynı şekilde karşılık bulmamıştır. Nitekim Fıkıh ilminde genellikle 'Delil' ve 'Kâide' olarak ${ }^{35}$ anlamlandırılan usûl kavramı; Kelâm

32 İbrahim Görener, Tefsir ve Tefsir Usûlü Üzerine Düşünceler, 22-25.

33 İbrahim Emiroğlu, Klasik Mantığa Giriş, (Ankara: Elis Yayınları, 2016), 38-55.

34 Muhammed b. Muhammed el-Gazzâlî, el-Mustasfâ min 'Ilmi'I-Usûl, (Medine: yayınevi yok, Tsz), 22-25.

35 et-Tehânevî, Keşşâf-u Istılâhâti'l-Fünûn, I, 213; Ali Haydar Efendi, Usûl-i Fıkıh Dersleri, (Istanbul: Üçdal Neşriyat, 1966), 8-9; Talip Türcan, "Fıkıh Usûlü: Tanım Tarihçe ve Tedvin", Fıkıh Usûlü El Kitabı içinde, ed: Talip Türcan, (Ankara: Grafiker Yayınları, 2019), 20. 
ilminde, İslâmî ilimlere temel teşkil etmesi sebebiyle ‘Usûlü'd-Dîn' şeklinde itîkadî bağlamda kullanılmıştır. ${ }^{36}$ Hadis ilminde ise 'Usûl' kavramı; 'Hz Peygamber'e nispet edilen söz, fiil ve davranışların kabul ve ret yönünden durumlarını inceleyen ilim' olarak kabul edilmektedir. ${ }^{37}$

Bizim burada vurgulamak istediğimiz husus; usûl kavramının diğer ilimlerle kazandığı anlamın tefsir ilminde de beklenmesi problemidir. Yani Fıkıh, Hadis ve Kelam usûlünün zihinlere kazandırdığı anlam yoğunluğu, Tefsir Usûlü'nde de aynı beklentiyi oluşturmuştur. Ancak bu kavramın, her terkipte farklı anlamlar ortaya koyduğu ve metodoloji ya da anlamaya dayalı teknik bir yöntem sunmadığı da bilinen bir gerçektir. ${ }^{38}$ Bu sebeple Fıkıh, Hadis veya Kelam ilmindeki usûl anlayışının aynısını Tefsir Usûlü'nden beklemek isabetli bir tavır değildir. Çünkü bu ilimlerin her birinde usûl kavramı, terkip oluşturduğu ilme/kelimeye göre farklı bir anlam ve içerik kazanmaktadır.

Usûl kavramının, ıstılah haline gelmeden önce ${ }^{39}$ müfessirler tarafından tefsirlerde bazı tanımları yapılmıştır. Müfessirlerin yaptığı bu tanımlar genellikle eserlerinin mukaddimelerinde yer almaktadır. Ahkâmü'l-Kur'ân müelliflerinden Cessâs (ö.370/981) usûl kavramını, tevhid kelimesiyle birlikte (Usûlü't-Tevhîd) kullanmaktadır. ${ }^{40}$ Bir diğer Ahkâm tefsiri müellifi Kurtubî'nin (ö. 671/1273) usûl kavramını; "Peygamberden sonra Kur'ân'ın dikkat çektiği anlamları ve işaret ettiği usûlü (اشار الى اصوله) tespit etme yetkisi ilim adamlarına verilmiştir." diyerek Kur'ân'ın temel esasları bağlamında kullandığı görülmektedir. ${ }^{41}$

el-Keşşâf müellifi Zemahşerî (ö. 538/1143) usûl kavramını Usûlü'd-Dîniyye terkibi şeklinde kullanmıştır. Müellifin Usûlü'd-Dîniyye kavramı ile ne kastettiğini tam

36 et-Tehânevî, Keş̧̧âf-u Istılâhâti'l-Fünûn, I, 213.

37 et-Tehânevî, Keşşâf-u Istılâhâti'l-Fünûn, I, 36.

38 Usûl kavramı terkip oluşturduğu Hadis Usûlü'nde de anlamaya veya yorumlamaya dair teknik bir anlamda kullanılmamaktadır. Kavram burada kendi disiplini içerisinde farklı bir anlam kazanmıştır. Bkz: Mehmet Görmez, Sünnet ve Hadisin Anlaşılması ve Yorumlanmasında Metodoloji Sorunu, (Ankara: Türkiye Diyanet Vakfı Yayınları, 1997), 97.

39 'Istılah haline gelmeden önce'den kastettiğimiz zaman dilimi, Usûl kavramının Tefsir Usûlü terkibi şeklinde İbn Teymiyye'nin Mukaddime fî Usûli't-Tefsir adlı eserinin telifi edildiği zamana kadar geçen zaman dilimidir.

40 Ebu Bekr Muhammed b. Ali el-Cessâs, Ahkâmü'l-Kur'ân, (Beyrut: Dâr-u İhyâi't-Türâsi'l-Arabî, 1992), I, 5-8.

41 Ebû Abdillah Muhammed b. Ahmed b. Ebî Bekr el-Kurtubî, el-Câmi' li Ahkâmi'l-Kur'ân, (Beyrut: Müessesetü'r-Risâle, 2006), l, 7. 
olarak belirleyemesek de kavramın kullanıldığı bağlamdan hareketle itikadî bir anlam içerdiği kanaatini taşımaktayız. ${ }^{42}$

Osmanlı dönemi müfessirlerinden Ebu's-Suud Efendi (ö. 982/1574) eserinin mukaddimesinde Tefsir tarihine dair kısa bir bilgi vermiş, eserini niçin kaleme aldığını izah etmiş ancak Tefsir Usûlü kavramı bağlamında herhangi bir açıklamada bulunmamıştır. Aynı durum Beydâvî'nin tefsiri için de geçerlidir. ${ }^{43}$ Müfessir Beğavî (ö. 516/1122) de ilk müfessirleri zikrederek başladığı mukaddimesinde Kur'ân ilimlerinden bazılarına değinmiş ancak usûl kavramı hakkında herhangi bir açıklamada bulunmamıştır. ${ }^{44}$

Son dönem müfessirlerinden Mustafa el-Merağî (ö. 1952) eserinin mukaddimesinde Tefsir Tarihi ve Resmü'l-Hat hakkında malumat verdiği halde Usûl ve Ulûmu'l-Kur'ân kavramlarının mâhiyetine dair herhangi bir açıklama yapmamıştır. ${ }^{45}$ Tâhir b. Âşur (ö. 1973) ise tefsirinin mukaddimesinde usûl kavramını Sekkâkî'den (ö. 626/1229) alıntı yaparak kullanmıştır. Arap dili ve belağatının, Kur'ân'ın maksadını doğru anlamada çok önemli olduğunu örneklerle vurguladıktan sonra 'llmu'l-Usûl ( علم الاصول) terkibiyle bu kavramı kullanmıştır. Kavramın bağlamını dil ağırlıklı ve doğru anlama üzerine kuran İbn Âşur, Sekkâki'yi düşüncesine şahit olarak getirmiştir. ${ }^{46}$

Muhammed Emin eş-Şinkıtî (ö. 1974) de eserinin mukaddimesinde Usûlü't-Tefsir terkibini kullanmasa da usûl kavramını müfret veya başka lafızlarla birlikte terkip halinde kullanmıştır. Usûl kavramını müfret olarak kullandığı yerlerde ${ }^{47}$ 'Kur'ân'ı anlamada yöntem' mânâsını kastetmiş; terkip olarak kullandığı ${ }^{48}$ yerlerde ise

42 Ebu'l-Kasım Mahmud b. Ömer ez-Zemahşerî, el-Keşşâf an Hakâiki't-Tenzîl ve Uyûni'l-Ekâvîl fî Vücûhi't-Te'vîl, (Beyrut: Dâr-u İbn Hazm, 2012), 8; ; Abdullah b. Ömer b. Muhammed el-Beydavî, Envâru't-Tenzîl ve Esrâru't-Te'vîl, (Beyrut: Dâr-u İhyâi't-Türâsi'l-Arabî, Tsz), I, 23-24.

43 Ebu's-Suud b. Muhammed el-Imâdî el-Hanefî, Irşâdü'l-Aklı's-Selîm ilâ Mezâye'l-Kitâbi'l-Kerîm, (Riyad: Mektebetü'r-Riyad el-Hadîse, Tsz), I, 1-8.

44 Ebû Muhammed Hüseyin b. Mesud el-Beğavî, Meâlimü't-Tenzîl, (Kahire: ed-Dâru'l-Âlemiyye, 2015), I, 3-19.

45 Ahmed Mustafa el-Merağî, Tefsîru'l-Merağî, (Kahire: Mustafa el-Bâbî el-Halebî, 1946), I, 3-19.

46 Muhammed Tâhir İbn Âşûr, et-Tahrîr ve't-Tenvîr, (Tunus: ed-Dâru't-Tunusiyye, 1984), I, 20.

47 Muhammed Emin eş-Şinkıtî, Eḍâü'l-Beyân fî l̇żâhi'l-Ḳur'ân bi'l-Kur'ân, (Mekke: Dâr-u Âlemi'l-Fevâid, h.1426), I, 26.

48 Müellifin, mukaddimenin birçok yerinde Usûl kavramını müfret şekliyle kullanmasını Usûlü'd-Din bağlamında ele alan araştırmacıların olması muhtemeldir. Ancak müellifin bu kavramı müfret olarak kullandığı yerlerde bağlamın Kur'ân'ı anlamaya yönelik bir yönünün olduğu da aşikârdır. Bkz: eş-Şinkıtî, Eḍvâü'l-Beyân fî l̇̇̇âhi'l-Ḳur'ân bi'l-Ḳur'ân, I, 27, 29, 30. 
usûlün mahiyetine dair bir açıklamada bulunmamıştır.

Müfessirlerin konu hakkındaki görüşlerini naklettikten sonra değinmek istediğimiz bir husus da Kur'ân'ı anlamaya dair metot/yöntem iddiasında bulunan eserlerin varlığıdır. Özellikle son dönemde Kur'ân'ı Anlamada Yöntem, Kur'ân'ı Anlamada Usûl, Kur'ân'ı Anlama Yöntemi, Kur'ân ve Yorum gibi farklı başlıklarla kaleme alınan bu eserleri ${ }^{49}$ incelediğimizde Tefsir ilmine dair bir usûl anlayışı geliştirmede yeterli olmadıklarını görmekteyiz. Hem Türkiye'de hem de İslâm coğrafyasında yazılan bu eserlerden tercümesi yapılanların Kur'ân'ı anlamaya dair başlıklarla yayımlanmasını da anlamlı bulmuyoruz. ${ }^{50}$ Zira bu eserler, başlık ile içeriğin uyumsuz olması ya da bir mülâkatın yazıya dökülerek kitaplaştırılması gibi ilmî tavırdan uzak yapıları sebebiyle ciddi problemleri barındırmaktadır. Özellikle Kur'ân'ı anlama bağlamında başlıkta okuyucuya vaad ettikleri hususu eserlerde neredeyse hiç işlememektedirler.

Bu bilgilerden sonra Tefsir ilminde usûl kavramının tanımını yapmak için bu kavramın ilk olarak kullanıldığı yeri tespit etmek önceliğimiz olacaktır. Usûl kavramını eserinde dile getiren ilk müellifin İbn Teymiyye (ö. 728/1328) olduğu kabul edilmektedir. ${ }^{51}$ İbn Teymiyye Mukaddime fi Usûli't-Tefsîr adlı kitabını yazma sebebini 'Kur'ân'ı anlamada belirleyici ve Tefsir kitaplarında yer alan doğru ile yanlışları birbirinden ayırt edici küllî kâideleri içeren bir eser' kaleme almak şeklinde açıklamıştır. ${ }^{52}$ Tefsir Usûlü'ne giriş bağlamında kaleme alınan bu eserin ana teması 'Kur'ân'ın doğru anlaşılması'dır.

Eserinin adına usûl kavramını dâhil eden Şah Veliyyullah ed-Dihlevî (ö. 1176/1762) ise usûl kavramılla ilgili bir açıklama yapmasa da niçin bu adı koyduğuna dair izahatta bulunmuştur. Risâlesini telif etme maksadını beş madde 2016); İzzet Derveze, Kur'ân'ı Anlamada Usûl çev. Vahdettin İnce, (İstanbul: Ekin Yayınları, 2017); Mustafa Müslim, Kur'ân Çalışmalarında Yöntem çev. Salih Özer, (Ankara: Fecr Yayınevi, 1998); Dücane Cündioğlu, Kur'ân'ı Anlamanın Anlamı, (İstanbul: Kapı Yayınları, 2016); Mehmet Soyz saldı, Kur'ân'ı Anlama Metodolojisi, (Ankara: Fecr Yayınevi, 2001); Anlam ve Yorum bağlamında yazılan eserleri bu konuya dâhil etmedik. Çünkü yorum merkezli yazılan bu tür eserlerde, usûl iddiasından ziyade bazı konuların nasıl anlaşılması gerektiği üzerinde durulmaktadır.

50 İzzet Derveze'ye ait el-Kur'ânü'I-Mecîd adlı eser Kur'ân'ı Anlamada Usûl başlığıyla Türkçeye tercüme edilmiştir. Ömer Ubeyd Hasene'nin Muhammed Gazâlî́yle; Kur'ân, Tefsir ve bu konularla ilgili bazı başlıklar merkezinde yaptığı söyleşilerin de Kur'ân’ı Anlamada Yöntem olarak Türkçeye kazandırıldığı görülmektedir. 
ile açıklayan müellif, eserindeki bilgilerin Kur'ân'ın mânâlarını anlamada kolaylık sağlayacağını dile getirmiştir. Bir metodoloji iddiasından bulunmaktan öte anlamanın derinliğine ve vukûfiyetine değinen müellif, bunun Allah'ın sınırsız lütfu sayesinde olacağına da vurgu yapmaktadır. ${ }^{53}$

Tefsir Usûlü kavramının ortaya çıktığı bu dönemde mahiyetine dair net bir tarif yapılmamış olsa da bu kavram hakkında yapılan açıklamalar genellikle 'Kur'ân'ı doğru anlamak' ekseninde gerçekleşmiştir. Ancak daha sonra Tefsir Usûlü ile Ulûmu'l-Kur'ân kavramlarının içerik ve mahiyeti ile ilgili meydana gelen tanım karmaşasının ardından bazı müellifler, bu iki kavramın mahiyetini açıklamaya çalışmışlardır. Zamanla Kavâidü't-Tefsir kavramının bu iki kavrama anlam olarak yaklaşması durumu biraz daha girift hale getirmiştir. Özellikle 19. ve 20. yüzyılda Tefsir Usûlü alanıyla ilgili yapılan çalışmalara konu olan bu kavramlar, tarifleri yapılırken birbirinden ayırt edilmeye çalışılmıştır.

XIX. ve XX. yüzyılda yapılan çalışmalarda Tefsir Usûlü kavramının anlamı, ortaya çıktığı ilk dönemdeki manasından biraz daha farklı bir alana kaymıştır. Sabbâğ (ö. 2017) eserinde Tefsir Usûlü'nün, Kur'ân'ın tahrif edilmesi/aslının değiştirilmesi ve manasının ifsat edilmesinin/bozulmasının önünde önemli bir engel olduğuna vurgu yapmış ve Tefsir Usûlü'nü şu şekilde açıklamıştır: Tefsire başlamadan önce müfessirin yerine getirmesi gereken şartları belirten, zarûrî ve önemli kâideleri koyan bir ilimdir..54 Bu tarifi ile Sabbâğ, 'Tefsire başlamadan önce müfessirin yerine getirmesi gereken şartlar' ile Ulûmu'I-Kur'ân'a; 'zarûrî ve önemli kâideleri koyan bir ilimdir'ile de Kavâidü't-Tefsir'in tarifine yaklaşmıştır. Aslında Sabbâğ'ın tarif ettiği Tefsir Usûlü tanımı, bu konu ile ilgili yazılan bütün eserlerde ortak payda olarak karşımıza çıkmaktadır. el-Akk da Tefsir Usûlü'nün tarifinde 'Tefsir'in kendisi üzerine bina edildiği kâide ve yöntemler' diyerek ${ }^{55}$ Sabbâğ'ın tarifinin ikinci kısmı ile aynı vurguyu yapmış ve Kavâidü't-Tefsir'in tarifine yaklaşmıştır.

Arap coğrafyasında yapılan çalışmaları incelediğimizde Tefsir Usûlü tanımının genellikle iki yönlü olarak ele alındığını görmekteyiz. Bunların birinci yönü Ulûmu'l-Kur'ân'a yakın anlamlı tarifler, ikinci yönü ise Kavâidü't-Tefsir'e yakın tariflerdir. Yukarıda ismi geçen müelliflere ek olarak Arap coğrafyasında konu ile ilgili eser veren Fehd er-Rûmî, Müsâid b. Süleyman, İsmail b. Osman, Halil b. İbrahim 
el-Hüseynî gibi âlimler de Usûlü't-Tefsir'in tanımını yapmışlar ancak mevcut tariflerin dışına çıkamamışlardır. ${ }^{56}$

Eserlerine usûl kavramını kullanarak başlık koyan ancak Tefsir Usûlü’nün tanımına hiç değinmeyen müellifler de vardır. Bu müelliflerden Mennâu'l-Kattân, Usûlü't-Tefsir kavramını eserinde tarif etmemiş ancak eserinin birinci bölümünde Usûlü't-Tefsir ile neyi kastettiğini ifade etmiştir. el-Kattân'Müfessirin Kur'ân'ı anlamada ihtiyaç duyduğu kâideler' olarak nitelediği eserini 'elfâz ve delâlet' bahisleri ağırlıklı olarak telif etmiştir. ${ }^{57}$ Bu konuda Mennâu'l-Kattân ile aynı bakış açısıyla eser veren diğer müellifler ise Muhsin Abdulhamit ve Muhammed b. Salih el-Useymin'dir. el-Useymin, eserini Kur'ân Tarihi, Tefsir Tarihi ve bazı Ulûmu'l-Kur'ân konularını merkeze alarak yazmıştır. ${ }^{58}$ Muhsin Abdulhamit ise Mennâu'l-Kattân gibi 'elfâz ve delâlet' konularının ağırlıklı olarak işlendiği bir eser kaleme almıştır. ${ }^{59}$

Ülkemizdeki ilk çalışmalardan kabul edilen Tefsir Usûlü isimli eserinde İsmail Cerrahoğlu Tefsir Usûlü'nü; 'Beşerin gücü ve Arapça'ya olan vukûfiyeti nisbetince Kur'ân'dan nasıl çıkarımlar yapacağını gösteren kâide ve usuller mecmuasıdır' şeklinde tarif etmiştir. Metodoloji iddiası ağırlıklı olan bu tarifin devamında Cerrahoğlu başka bir duruma daha vurgu yapmış; 'kolaylıkla anlaşılması mümkün olmayan âyetlerin üzerine derinlemesine düşünmemizi Tefsir Usûlü sağlar ve konu ile ilgili âyeti kolaylıkla anlarız' demiştir. ${ }^{60}$

Son dönemde Türkiye'de yapılan Tefsir Usûlü çalışmalarında bazı ilim adamları konu ile ilgili farklı tarifler yapmışlardır. Bunlardan İsmail Çalışkan'ın yaptığı Tefsir Usûlü tanımı, son dönemde yapılan ve mâhiyeti açısından önemli gördüğümüz bir tanımdır. Çalışkan'a göre Tefsir Usûlü; Kur'ân'ın anlaşılması ve yorumlanması sırasında uyulması gerekenleri anlatan disipline denir. ${ }^{61}$ Muhsin Demirci'nin Tef-

Fehd b. Süleyman er-Rûmî, Buhûs fî Usûli't-Tefsîr ve Menâhicuhû, (Riyad: Mektebetü't-Tevbe, 1996), 11; Müsâid b. Süleyman et-Tayyâr, Füsûlün fî Usûli't-Tefsîr, (Riyad: Dâru'n-Neşri'd-Düvelî, 1993), 11; Müsâid b. Süleyman Nâsır et-Tayyâr, et-Tahrîr fí Usûli't-Tefsîr, (Cidde: Merkezü'd-Dirâseti ve'I-Ma'lûmeti'l-Kuraniyye, 2014), 16; İsmail b. Osman ez-Zeynü'l-Mekkî, el-Kavlü'l-Münîr fî 'Ilmi Usûli't-Tefsir, (Riyad: el-Maârifü'l-Kur'âniyye, 2007), 21; Halil b. İbrahim el-Hüseynî, ed-Dürru'n-Nesîr fî Usûli't-Tefsîr, (Kahire: Dâru'r-Risâle, 1993), 4. Mennâu'l-Kattân, el-Vecîz fî Usûli't-Tefsir, (Riyad: Matbaatü's-Selefiyye, h.1379), 4.

58 Muhammed b. Salih el-Useymin, Şerhu Usûlin fi't-Tefsir, (Riyad: Müessesetü Şeyh Muhammed b. Salih el-Useymin el-Hayriyye, h.1434), 5-391.

59 Muhsin Abdulhamit, Dirâsât fî Usûli Tefsiri'l-Kur'ân, (Mağrib: Dâru's-Sakâfe, 1984), 7-163.

60 İsmail Cerrahoğlu, Tefsir Usûlü, (Ankara: Türkiye Diyanet Vakfı Yayınları, 2008), 7.

61 İsmail Çalışkan, Tefsir Usûlü, (Ankara: Ankara Okulu Yayınları, 2017), 15-16. 
sir Usûlü tanımı ise 'Kur'ân'ın anlaşılması ve yorumlanması bağlamında gerekli ilke ve yöntemleri ortaya koyan ve bunların nasıl kullanılacağını gösteren bilgiler' şeklindedir. ${ }^{62}$ Demirci ve Çalışkan'ın tarifine göre bir müfessir adayı, Kur'ân'ı yorumlamadan önce uyulması gereken bazı kuralları kabul edip faaliyeti esnasında bunları kullanmalıdır. Bir metodoloji iddiasını içinde barındıran bu tanımlara göre 'yorumlama faaliyeti esnasında yapılması gerekenler'den kastedilen 'kurallar bütünü' ise bu daha çok Kavâidü't-Tefsir'in tanımına yakın bir tariftir. Bununla birlikte tariflerde geçen 'uyulması gereken bilgiler'den kastedilen eğer Kur'ân'ı yorumlamadan önce bilinmesi gereken bilgiler ise bu da ileride yapacağımız Ulûmu'l-Kur'ân tarifine karşııık gelmektedir.

Ülkemizde bu alanda yazılan son eserlerden biri de Ömer Dumlu'ya ait Tefsir Usûlü adlı eserdir. Dumlu, eserinde Demirci ve Çalışkan'ın tanımına yakın bir tarif ile Tefsir Usûlü'nü 'müfessiri âyetler konusunda hataya düşmekten alıkoyan ölçüler' şeklinde tarif eder. ${ }^{63}$ Ancak Dumlu da diğer müellifler gibi bu ölçünün ne olduğu konusunda eserinde herhangi bir açıklamaya yer vermemiştir.

Kur'ân Illimleri ve Tefsir Usûlü eserinin müellifi Bilal Deliser'e göre Tefsir Usûlü; 'Kur'ân'ın anlaşılması ve yorumlanmasında kullanılacak tarihsel bilgileri sunan ve bununla birlikte yorumlamanın bir takım ilke ve yöntemlerini ortaya koymak suretiyle bunlardan nasıl yararlanılacağını gösteren ilim dalıdır.64 Deliser'in tanımındaki 'tarihsel bilgileri sunan' kısmıyla; Kur'ân Tarihi ve Ulûmu'l-Kur'ân merkezli bilgileri kastettiği kanaatindeyiz. Tarifinin ikinci bölümü olan 'yöntemlerini ortaya koymak' kısmıyla da bizim teklif edeceğimiz tarife yaklaşmaktadır.

Tefsir Usûlü, Ulûmu'l-Kur'ân ve Kavâidü't-Tefsir'i bünyesinde taşımakla birlikte Fıkıh Usûlü gibi sistematik bir yapıya sahip değildir. Bundan dolayı Tefsir Usûlü'nün bir metodoloji içermediğini ifade eden eleştiriler sürekli olmuştur. Ancak şu unutulmamalıdır ki tarihî süreçte bu üç kavramla ilgili sınırları belli, net tariflerin yapılmaması ve özellikle Usûlü't-Tefsir kavramının mahiyet ve içeriğinin belirlenmemesi konumuzu biraz daha önemli hale getirmektedir.

Bir metni veya söz öbeğini yorumlamak teknik bir bilgi birikimini gerektirse de Kur'ân yorumunda bu durum kişisel beceri ile de yakından alakalıdır. İşte Kur'ân'ın 
yorumlanması faaliyeti esnasında, altyapı bilgisi olan Ulûmu'l-Kur'ân ve Kavâidü't-Tefsir ile örülen bir yaklaşım tarzı müfessir adayının usûlünü oluşturmaktadır. Müfessir adaylarının usûlî yaklaşımla elde ettiği sonuçların birbirinden farklı olması da bizim yorum zenginliğimiz olarak ilmî mirasımızın arasında yerini alacaktır.

\subsubsection{Tefsir IIIminde Usûl Kavramına Yöneltilen Eleştiriler, Öneriler ve Anlam Arayışı}

Tefsir Usûlü'nün varlığı ile ilgili ontolojik tartışmalara girmeden, Tefsir Usûlü’nün günümüzde anlamaya dair bir teklif sunmadığı yönünde eleştiriler yöneltildiğini ${ }^{65}$ belirtmeliyiz. Bu eleştiriler, bazen metodolojik yönü göz önüne alınarak bazen de diğer ilimlerin usûlleri ile kıyas edilerek yapılmaktadır. Tefsir Usûlü, işlevi ve yapısıyla ilgili birçok tartışmaya konu olmuş; buna rağmen bu kavrama dair sadra şifa bir netice elde edilememiştir. Tekâmülünü tam olarak gerçekleştiremediğini düşündüğümüz Tefsir Usûlü kavramının, belki de kendisinden her dönem farklı beklentilerin olması sebebiyle tarifleri de değişmektedir.

Tefsir Usûlü'ne getirilen eleştirilerden bir diğeri de Tefsir Usûlü kavramının Kur'ân'ı anlamaya yardım eden bir yönünün olmaması ${ }^{66}$ sebebiyle tekrar gözden geçirilmesi gerektiği meselesidir. ${ }^{67}$ Bununla birlikte bu eleştiriye çözüm olarak sunulan nesh ve tearuz gibi konuların Fıkıh Usûlü'nün içinde olması gerektiğini dile getirmek, usûlî bir anlayışla Kur'ân'a yaklaşımı sınırlandırmakta ve bazı âyetlerin bazı ilim dallarına tahsisi gibi olumsuz sonuçlar doğurmaktadır.

Tefsir Usûlü'nden, 'anlamanın usûlü' olması yönünde bir beklenti oluştuğunu, Tefsir Usûlü'nün ise bu beklentiye cevap verememesi veya bir metot geliştirememesi sebebiyle eleştirildiğini de görmekteyiz. ${ }^{68}$ Bu beklentinin sebebi olarak usûl kavramının diğer İslâmî ilimlerdeki kullanımını ve işlevini gösterebiliriz. Yani Fıkıh Usûlü ekseninde düşünülen usûl kavramının, Tefsir Usûlü'nde de aynı şekilretiminin Problemleri, (Bursa: Kurav Yayınları, 2007), 30.

67 Gıyasettin Arslan, 'Tefsir Usûlü'ne Fıkıh Usûlü Karıştırmak', Fırat Üniversitesi Ilahiyat Fakültesi Dergisi, 13/2 (2008): 32.

68 Mehmet Paçacı, Kur'ân ve Ben Ne Kadar Tarihseliz, (Ankara: Ankara Okulu Yayınları, 2016), 38-41; M. Sait Şimşek, "Illahiyat Fakültelerinde Tefsir Dersi-Problemler ve Öneriler", 30; Celal Kırca, "Müzakere", İslâmî Illimlerde Metodoloji (Usûl) Meselesi-I, (İstanbul: Ensar Yayınları, 2005), 622-625: M. Sait Şimşek, "Müzakere", İslâmî ilimlerde Metodoloji (Usûl) Meselesi-I, (İstanbul: Ensar Yayınları, 2005), 628-630; Hayri Kırbaşoğlu, İslâmî Illimlerde Metot Sorunu, (Ankara: Otto Yayınları, 2015), 16-17. 
de kullanılması anlam karmaşasına sebebiyet vermektedir. Netice itibariyle Tefsir Usûlü'ne getirilen eleştirileri özetleyecek olursak;

1-Kur'ân'ı anlamaya dâir bir metodoloji sunmaması ${ }^{69}$,

2-Kur'ân'ı anlamaya yardım eden bir yönünün olmaması ${ }^{70}$,

3-Fıkıh Usûlü gibi metodik bir yönünün bulunmaması ${ }^{71}$ şeklindedir.

Tefsir Usûlü'ne eleştirel yaklaşım sergileyen bazı müellifler, İslâmî ilimler geleneğindeki mantık süzgeciyle oluşan Kur'ân'ı anlama yöntemini toptan reddetmektedir. Ancak bu eleştirel yaklaşımları kabul edecek olursak, bu durum günümüze kadar elde edilen bilgi birikiminin yok sayılması gibi bir riski de içinde barındıracaktır. Bununla birlikte bu kabul neticesinde âyetlerdeki anlam-mânâ dengesini kurmak zorlaşacak ve sınırları belli olmayan bir yaklaşımla Kur'ân'ın yorumlanmasına kapı aralanacaktır.

Telif edilen tefsirlere baktığımızda hemen hemen hepsinin aynı bilgi kaynağını (Ulûmu'l-Kur'ân ya da Kavâidü't-Tefsir) kullandıkları halde âyetleri farklı şekilde yorumladıklarını ya da lafızların müsaade ettiği ölçüde farklı tercihlerde bulunduklarını görmekteyiz. Bu durum; tefsir faaliyetinde bir usûl anlayışının olmadığı anlamına gelmemektedir. Ancak bu öznellik Kur'ân lafızlarının kişiye, fikirlerini ve bu fikirler doğrultusundaki tercihlerini eserine aksettirme imkânı sunması ile gerçekleşir.

Kur'ân'ı anlama çabası esnasında mânânın doğru yakalanabilmesi için İslâmî diğer ilimlerden de istifade edilebilmelidir. Modern dönemde bu ilimlerin tasnifinin net çizgilerle belirlendiği gerçeğini bilsek de ahkâm âyetleri boyutuyla Fıkıh ilminden, bazı âyetlerin açıklanması boyutuyla Hadis ilminden ve itikadî-inanç merkezli âyetlerin anlaşılması boyutuyla da Kelam ilminden istifade edilebilir. Aslında bu istifade, ilimler arasındaki iletişim ve etkileşim sebebiyle zorunluluk olarak da karşımıza çıkmaktadır. Daha çok Fıkıh Usûlü'nde başlık olarak işlenen 'elfâz ve delâlet' konusu aynı zamanda Tefsir'in ve usûlünün de konusudur. Yine aynı şekilde 'Halku'l-Kur'ân' konusu tarihte gerçekleşen kelamî bir tartışmanın uzantısı olarak her dönem olmasa da Tefsir Usûlü'nde kendine yer bulan konular arasındadır. ${ }^{72}$ 
İlk dönemden hicrî VII.-IX. yüzyıllar arasında özellikle Tefsir Usûlü ve Ulûmu'l-Kur'ân başlığıyla yazılan eserlerin bir kısmında metodoloji ortaya koyma gayreti olduğunu görmekteyiz. İbnü'l-Cevzî (ö. 592/1201), Makdîsî (ö. 665/1266), Zerkeşî (ö. 794/1392), Bulkınî (ö. 824/1421), Kâfiyecî (ö. 879/1474) ve Suyutî'nin (ö. 911/1505) de içinde bulunduğu dönemde Tefsir ilmi alanında kıymetli eserler yazılmıştır. Bu dönem müelliflerinden özellikle Kâfiyecî (ö. 879/1474) eserini diğer müelliflerden farklı bir bakış açısıyla kaleme almıştır.

Bir disiplinin ilim olup olmamasının temelini mantıktaki burhân delili üzerinden açıklamaya çalışan ilim adamları bunu genellikle mevzu, mesâil ve mebâdî kavramları $^{73}$ üzerinden ele almışlardır. Illk dönemlerde Fârâbî (ö.339/950) ve İbn Sîna (ö. 428/1037) tarafından yapılan bu tarife daha sonra Teftâzânî (ö.792/1390) de katılmıştır. ${ }^{74}$ İşte Kâfiyecî’yi dönemindeki diğer müelliflerden ayıran özellik, Tefsir Usûlü'nün inşasına yukarıda ismini saydığımız ilim adamlarının bilgi anlayışına uygun olarak girişmesidir.

Tefsir Usûlü ve Ulûmu'l-Kur'ân başlığıyla bu döneme kadar yazılan eserleri incelediğimizde, usûl anlayışının müellifler tarafından iki farklı şekilde ele alındığını görmekteyiz. Söz konusu anlayışlardan ilki; Ulûmu'l-Kur'ân'a dair bilgiler ışığında yapılan tefsirin, makbul olduğunu ifade eden müelliflerin bakış açısıdır. Bu bakış açısına sahip müelliflerin başında Zerkeşî (ö. 794/1392) ve Süyûtî (ö. 911/1505) gelmektedir. Buna göre bu müfessirler; tefsir faaliyeti esnasında usûlî bakış açısının, Ulûmu'l-Kur'ân bilgileri ışığında yapılan tefsirle ortaya çıktığı kanaatini taşımaktadırlar. İkinci anlayış ise tefsirde Ulûmu'l-Kur'ân bilgilerinden ziyade makâsıdı önceleyen, dil ve mantık ilminin bazı unsurlarını da usûle dâhil eden bakış açısıdır. Bu bakış açısının en büyük temsilcisi olarak Kâfiyeci karşımıza çıkmaktadır. ${ }^{75}$ Bizim burada vurgulamak istediğimiz husus ise Süyûtî'nin, hocası Eczâü'I-Ulûm denir ki ifade ettiği kavramlar da Mevzû, Mebâdî ve Mesâil'dir. Yani ilimlerin kısımları; konuları, ilkeleri ve problemleri olmak üzere üç'tür. Kâfiyeci eserini Eczâü'l-Ulûm çerçevesinde Mevzû, Mebâdî ve Mesâil kavramları ile şekillendirmiştir. Konuyla ilgili ayrıntılı açıklama ileride gelecektir. Bkz: Kâfiyeci, Kitâbü't-Teysîr fi Kavâidi 'Ilmi't-Tefsîr, (Ankara: Ankara Üniversitesi İlahiyat Fakültesi Yayınları, 1974), 55, 66; et-Teftâzânî, Tehzibu'I-Mantık ve'l-Kelam, (Mısır: Matbaatü's-Saade, 1912), 14.

74 Sadettin et-Teftâzânî, Tehzibu'I-Mantık ve'I-Kelam, 14.

75 Mâlikî fakîh İbn Arafe (ö. 803/1401), Kâfiyeci'den önce Usûlü't-Tefsir'i 'Kur'ân âyetlerinin mânâya delâlet eden yönlerinin keyfiyyetini bilme' olarak tanımlamıştır. Ancak biz bu eserin hem tefsir olarak yazılması hem de bizzat müellifin eliyle kaleme alınmayıp öğrencileri tarafından ders notu olarak tutulması sebebiyle dikkate almıyoruz. Bkz: Ebû Abdillah Muhammed b. Arafe et-Tunusî, Tefsîr-u Ibn Arafe, (Beyrut: Dâru'I-Kütübi'I-IImiyye, 2008), I, 19. 
Kâfiyeci hakkında söyledikleridir. Çünkü Süyûtî'nin hocası hakkındaki kanaati, tarihî süreçte algılanan Tefsir Usûlü anlayışını iki farklı şekilde tasnif etmemize delil teşkil etmektedir.

Süyûtî, hocası Kâfiyeci'nin 'Tefsir ilmini tedvin ettim'76 ifâdesini eleştirmektedir. Zîra Süyûtî, hocasının tedvinini 'Kur'ân ilimlerinin bir kitap içerisinde toplanması' olarak anlamaktadır. Bu sebeple o, hocasının Zerkeşî’ye ait el-Burhân ve Celaleddin Bulkînî'ye ait Mevâkıu'l-Ulûm adlı eserleri görmesi halinde bu iddiada bulunamayacağını dile getirir.77 Süyûtî'nin hocası Kâfiyeci'yi eleştirmesini normal karşılıyoruz. Zira o güne kadar yapılan tedvin tanımları ve girişilen tedvin faaliyetlerinin mâhiyeti onun bu kavramı bu şekilde anlamasına sebep olmuştur.

Süyûtî́nin tasavvurundaki 'ilimlerin tedvin'i tarifini Tehânevî (ö. 1158/1746) şu şekilde yapmıştır: 'Müdevven ilimler; sarf, nahiv, mantık, hikmet vb. ilimler gibi bilgileri kitaplarda toplanmış ilimlerdir. ${ }^{178}$ Tedvini Tefsir ilmi için düşündüğümüzde; rivâyet ve bilgilerin derlenerek bir kitap içinde cem edilmesini anlayabiliriz. Bu da bize tedvin faaliyetinin ilk etapta Kur'ânî ilimler ile ilgili bilgilerin bir kitap içerisinde toplanması şeklinde olduğunu göstermektedir. Bu da Süyûtî́nin anladığı tedvin anlayışıdır.

Kâfiyeci'nin tedvinden kastı ise bir ilmin, ilim olma kriterleri açısından tedvin edilmesidir. Diğer bir ifadeyle ilim dallarının, ilim olabilmeleri için taşımaları gereken bazı şartlar vardır ki bunlar; Eczâu'I-Ulûm olarak adlandırılan Mevzû, Mebâdî ve Mesâil'dir. Yani ilimler; konular, ilkeler ve problemler olmak üzere üç başlığı bünyelerinde barındırdıkları takdirde ilim olabilirler. ${ }^{79}$ Kâfiyeci'nin bu tedvin anlayışını ${ }^{80}$ Teftazânî'nin eseri olan Tehzîbu'l-Mantık ve'l-Kelâm'dan aldığı âşikardır. Çünkü Kâfiyeci, Teftazânî'nin bu eserini şerh etmiş ve Eczâu'l-Ulûm konusunu eserinde ayrıntılı olarak işlemiştir. ${ }^{81}$

Kâfiyeci, Kitâbü't-Teysîr fi Kavâidi 'Ilmi't-Tefsîr, 2.

Celaleddin Süyûtî, Buğyetü'I-Vuât fi Tabakâti'l-Lugavîyyin ve'n-Nuhât, (Beyrut: Dâru'l-Fikr, Tsz) I, 118; Abdü'l-Hayy b. Ahmed el-Hanbelî İbn 'Imâd, Şezerâtü'z-Zeheb fî Ahbâri men Zeheb, (Beyrut: Dâr-u İbn Kesir, 1989), IX, 489.

et-Tehânevî, Keşşâf-u Istılâhâti'l-Fünûn ve'l-Ulûm, c.1, s.3. et-Teftâzânî, Tehzibu'l-Mantık ve'l-Kelâm, s.14.

Tedvinin üç farklı tasnifi ve Kâiyeci'nin tedvin anlayışının değerlendirmesi için bkz: Halil ỉbrahim Kaygısız, 'Kâfiyeci'nin et-Teysir'de Tefsiri Müdevven Bir İlim Olarak Yeniden Tesis Etme Çabası', Osmanlı'da İlmi Tefsir (Editör: M. Taha Boyalık - Harun Abacı), İstanbul: İsar Yayınları, 2019, s.593-603.

Kâfiyeci, Şerhu Tehzîbi'l-Mantık, Süleymaniye Kütüphanesi, Laleli Koleksiyonu, no:2592, s. $91 \mathrm{~b}-95 \mathrm{~b}$. 
Kâfiyecî́nin tedvin kavramına bu anlamı yüklemesinde hocalarından Molla Fenârî́nin etkisi büyüktür. Çünkü hocasına göre tefsir; bir mârifet (bilgi) olması hasebiyle tedvin edilmemiştir.82 Kâfiyecî, eserinin herhangi bir yerinde hocasından böyle bir görüş nakletmemiştir. Ancak Kâfiyecî'nin konuyla ilgili kavram ve kâideleri tespit ederek Tefsir Usûlü'nü tesis etmeye çalışmasının altında hocasının bu iddiasının olması muhtemeldir. Belki de Kâfiyecî hocasına, eseri üzerinden reddiye sunmaktadır.

Netice olarak Tefsir ilminde amaç murad-ı ilahiyi anlamak ise buna hizmet edecek olan araçlar da Ulûmu'l-Kur'ân ve Kavâidü't-Tefsîr bilgileridir. Tefsir'in bir ilim olmadığını iddia edenler aslında bu ilmin bir usûlünün bulunmadığını da iddia etmektedirler. Ancak şu unutulmamalıdır ki İslâmî İlimlerin gelişim serüveninde ilimler; 'Kemâle ermiş', 'Olgunlaşmış ancak kemâle ermemiş' ve son olarak da 'Henüz olgunlaşmamış' ilimler olarak tasnif edilmektedir. ${ }^{83}$ 'Henüz olgunlaşmamış' ve 'gelişmeye açık' ilimlerden zikredilen Tefsir Usûlü ilmi, ${ }^{84}$ kanaatimize göre altyapısı olan Ulûmu'l-Kur'ân ve Kavâidü't-Tefsîr ilimleriyle birlikte olgunlaşma dönemini tamamlayacak ve kemâle erecektir.

\subsection{Kur'ân Illimleri/Ulûmu'I-Kur'ân}

'Ulûmu'I-Kur'ân' kavramı; 'ilm kelimesinin cem'isi olan 'ulûm' kelimesi ile 'Kur'ân' kelimesinin izafet terkibi şeklinde bir araya gelmesiyle oluşmuştur. Sözlükte;'Bilgi, anlamak, idrak etmek, denemek, öğrenmek, bir işi sağlam yapmak, kesin görüş sahibi olmak'85 gibi anlamlara gelen 'ilm kelimesi ıstılahta ise 'vâkıaya uygun bir îtikad ${ }^{86}$ veya 'bir şeyi hakikatine uygun şekilde idrâk etmek' ${ }^{87}$ anlamlarına gelmektedir.

Râzî (ö. 606/1210), Cüveynî (ö. 478/1085) ve Gazzâlî (ö. 505/1111) gibi âlimler ilmin tarifinin yapılamayacağını, yapılsa da çok zor olacağını dile getirmişlerdir. Ancak Tehânevî, eserinde ilmin çeşitleriyle birlikte farklı tasniflerini geniş bir şekilde açıklamaya çalışmıştır. ${ }^{88}$

Molla Fenârî, 'Aynu'l-Âyân Tefsîru Sûrati'l-Fâtiha, İstanbul, h.1326, s.4-5.

Emîn el-Hûlî, Menâhicu Tecdîdi fi'n-Nahv ve'l-Belâğa ve't-Tefsîr ve'l-Edeb, (Beyrut: Dâru'l-Marife, 1971), 302.

Muhammed b. Lütfi es-Sabbâğ, Buhûsün fî Usûli't-Tefsir, 12.

Halil b. Ahmed, Kitabü'l-Ayn, 675-676; İbn Manzûr, Lisânü'l-Arab, XII, 416-422.

Cürcânî, et-Ta'rîfât, 199.

Râgıb el-Isfahânî, el-Müfredât, 580.

et-Tehânevî, Keşşâf-u Istılâhâti'I-Fünûn ve'I-Ulûm, II, 1215-1230. 
'Ulûmu'l-Kur'ân' kavramını oluşturan iki kelimeden ilki olan 'ılm kelimesinin tarifini verdikten sonra Kur'ân kelimesinin tarifini yapmaya gerek duymuyoruz. Zira Kur'ân lafzının mâna olarak karşılığı zihinlerde net bir şekilde bulunmaktadır. Bundan dolayı biz ‘Ulûmu'l-Kur'ân' terkibi üzerinde yoğunlaşarak bu izâfetin anlam karşılığını netleştirmeye çalışacağız.

'Ulûmu'l-Kur'ân' terimi hakkında yapılan tarifler genellikle 'Kur'ân ile doğrudan veya dolaylı olarak ilişkili ilimler, Kur'ân'ın tefsiri ile ilgili olan ilimler merkezinde toplanmaktadır. Bununla birlikte bazen Ulûmu'I-Kur'ân konuları zikredilerek yapılan tarifler de vardır. ${ }^{89}$ Yapılan bu tariflerde vurgulamak istediğimiz iki husus bulunmaktadır:

Bunlardan ilki ez-Zürkâni'nin yaptığı tanımda gizlidir. Son dönemde kaleme aldığı eserinde Ulûmu'I-Kur'ân'ın önemini dile getiren Zürkâni, tarifini şu şekilde yapmıştır: 'Nüzûlü, tertibi, Kur'ân'ın derlenmesi, yazılıp okunması, i'cazı, nâsihi-mensûhu, kendisine yönlendirilen itirazların çürütülmesi vb. gibi konuları ele alan ilim dalıdır.'90 Ulûmu'I-Kur'ân'ın klasik tanımına 'Ulûmu'I-Kur'ân'a yönelik reddiyelerin çürütülmesini' de ekleyen müellif, tanıma yaptığı bu ekle, zamanın değişmesiyle Kur'ân'ı anlamaya temel teşkil edecek bilgilerin de sanki değişebileceğini kabul etmektedir.

Zamanın değişmesiyle bilimin gelişmesi yadsınamaz bir olgudur. Zamanın getirdiği yeni bilimsel bilgilerin ışığında âyetlerin daha iyi anlaşılması söz konusu olabilir. Bu veriler bazen Kur'ân âyetlerini tefsir etmede bazen de delil bağlamında kaynak olarak kullanılabilir. Ancak ez-Zürkânî'nin tarife eklediği 'reddiyelerin çürütülmesi' durumu, spesifik bir konu olup Ulûmu'l-Kur'ân'ın tanımına girmemesi gereken unsurlardan sayılmalıdır. Çünkü Zürkânî'nin tarife eklediği kısım; hem konunun önemi hem de çalışmaların daha derinlemesine ve ciddi bir şekilde yapılmasının gerekliliği sebebiyle özel olarak çalışılması gereken bir husustur. (Beyrut: el-Mektebetü'l-İslâmî, 2014), 261-262; Muhammed Ali es-Sâbûnî, et-Tibyân fî Ulûmi'l-Kur'ân, (İstanbul: Mektebetü's-Sirâc, Tsz), 8; Muhammed Kâsım eş-Şûm, Ulûmu'l-Kur'ân ve Menâhicü'l-Müfessirîn, (Beyrut: Dâru'I-Kütibi'I-İlmiyye, 2014), 13; İsmail Cerrahoğlu, Tefsir Usûlü, s.115; Mennâu'I-Kattân, Mebâhis fî Ulûmi'I-Kur'ân, (Beyrut: Müessesetü'r-Risâle, 2015), 16; Muhsin Demirci, Tefsir Usûlü, 129; Erdoğan Baş, 'Kur'ân İlimlerinin Doğuşu ve Tarihi Gelişimi (I-VI Asır)', Kur'ân ve Tefsir Araştırmları-III, (İstanbul: Ensar Yayınları, 2002), 22; Ömer Çelik, 'Hicrî V-XI Asırlarda Kur'ân İlimleri', 50. 
İkinci husus ise Kur'ân'ın anlaşılmasında yardımcı olan ilimlerin doğrudan ve dolaylı olanlar diye ikili şekilde tasnif edilmesidir. ${ }^{91}$ Bu tasnif şekli, subjektifliği içinde barındırması ve hangisinin doğrudan hangisinin dolaylı olacağının belirlenmesinin kişiye göre değişmesi gibi problemleri içinde barındırmaktadır. Ayrıca dolaylı olan bilgilerin genellikle pozitif ilimler kaynaklı olması ve modern bilimin getirdiği bilgilerin sürekli bir değişkenlik göstermesi sebebiyle biz bu bilgileri Kur'ân'ın anlaşılması ve yorumlanmasında zorunlu olarak bilinmesi gereken ilimler olarak görmüyoruz. ${ }^{92}$

Bizim burada vurgulamak istediğimiz bir diğer husus, Kur'ân'ın anlaşılmasında doğrudan etkili olan ilimlerin iç tasnifi ile alakalıdır. Son dönemde'Kur'ân'ın Lafzı, Anlamı ve Tarihi ile İlgili İlimler' şeklindeki başlıklarla genellikle üçlü hatta bazen sekizli tasnifi yapılmaktadır. ${ }^{93}$ Ancak bu tasnife 'Bağlam İçerikli İlimler'in eklenmesiyle Ulûmu'l-Kur'ân kapsamına giren ilimlerin dörtlü şekilde tasnif edilmesinin konuyu kategorize etmede daha isabetli olacağı kanaatindeyiz. Bu tasnifte 'bağlam'ın yer almasını uygun görmemizin sebebi; âyetlerin konumları sebebiyle iç bağlamın, nazil oldukları ortam ile ilişkileri sebebiyle dış bağlamın önemidir. İşte bu sebeple bağlam içerikli ilimleri de 'İç ve Dış Bağlam'ı göz önünde bulundurarak şekillendirmek, yapılan tasnifi daha anlaşılır hale getirecektir. ${ }^{94}$

Ulûmu'l-Kur'ân'a ait aslî konuların hangi başlıklar altında değerlendirilmesi gerektiğinin belirlenmesi ayrı bir çalışmanın konusudur. Bununla birlikte Ulûmu'l-Kur'ân, müfessir adayının faaliyetine girişmeden önce mutlaka bilmesi gereken bilgileri içermektedir. Bu bilgiler ışığında yapacağımız Ulûmu'I-Kur'ân tarifi şu şekildedir:

'Kur'ân'ın doğru anlaşılması ve yorumlanması için müfessir adayının tefsir faaliyetine girişmeden önce bilmesi gereken, Kur'ân ile doğrudan alakalı bilgileri içeren ilimler topluluğudur.'

92 Ömer Çelik, Ulûmu'l-Kur'ân ile kastedilen maksadın akla gelen gelmeyen her türlü ilim ve bilginin olmadığını dile getirmektedir. Bkz; Ömer Çelik, 'Hicrî V-Xı Asırlarda Kur'ân İlimleri', 50.

93 Muhsin Demirci, Tefsir Usûlü, 7-9; Bilal Deliser, Ulûmu'l-Kur'ân konularının iç tasnifinde sekiz başlık kullanmıştır. Konularının içeriği itibariyle birbirleriyle bağlantılı olan bu başlıklandırma şeklinin uygun olduğunu düşünmüyoruz. Bkz: Bilal Deliser, Kur'an Illimleri ve Tefsir Usûlü, 5-9.

94

'Bağlam' merkezinde yapılan birçok araştırma ve çalışma mevcuttur. Bu sebeple biz burada bağlamın üzerinde durarak onun ne olduğunu değil, tasnifteki yerinin ne olduğunu açıklamaya çalışacağız. Bununla birlikte 'Bağlam' kavramının analizini yapmak hem tezimizin merkezinden uzaklaşmamıza hem de gereksiz şekilde konunun uzamasına sebep olacağından bu kadarı ile yetineceğiz. 
Yani tefsir faaliyetine girişmeden önce Ulûmu'l-Kur'ân'ın mutlaka bilinmesi gerekir. Çünkü usûlî bir bakış açısıyla tefsir faaliyetine girişen kimse, bu bilgileri nerede ne şekilde kullanacağını bilmesinin yanında hangi bilgilerin Kur'ân'ı doğru anlamaya hangilerinin yardımcı olup olmayacağını da ayırt edebilecektir. ${ }^{95}$

\subsection{Kavâidü't-Tefsir}

Kavâidü't-Tefsir; kâide kelimesinin cemisi olan 'kavâid' kelimesi ile tefsir kelimesinin bir araya gelmesiyle oluşmuştur. Kâide kelimesi sözlükte; 'başkasının kendisine dayandığı şey, üzerine binanın yapıldığı sütun, asıl ve temel' anlamlarına gelmektedir. ${ }^{96}$

'Kavâid' kelimesinin ilim dallarının her biriyle ayrı ayrı terkip oluşturması, bu kavramın farklı anlamlarda ıstılahlaşmasına sebep olmaktadır. Bundan dolayı biz, çalışmamızın kavramsal çerçevesini sınırlandırmak adına bu terkibi Tefsîr ilmine muzâf olması itibariyle tarif edeceğiz.

Cürcânî kavâid kelimesini; 'Cüzlerin tamamına şâmil olan küllî önermeler' olarak tarif eder. ${ }^{97}$ Kavâidü't-Tefsir ise Osman es-Sebt tarafından; 'Kur'ân'ın mânâlarının keyfiyeti kendisiyle anlaşılan küllî önermeler' şeklinde tanımlanmıştır. Bu tarifin devamında yaptığı açıklamada müellif, Kavâidü't-Tefsir'in fonksiyonuna da dikkat çekmektedir. Özellikle müfessir adayının tefsir faaliyeti esnasında bu kâidelerin onu hata yapmaktan alıkoyacağını söyleyen müellif bu kâideleri, Allah'ın kelamını doğru anlamanın ölçütü olarak kabul etmektedir. ${ }^{98}$ Bununla birlikte 'kendileriyle Kur'ân'ın mânâlarının ve mâhiyetinin anlaşıldığı küllî hüküm, ilke ve prensipler bütünü'99 olarak da tanımları yapılmaktadır. sapmasına neden olabilmektedir. Özellikle sebeb-i nüzûl konusunda ortaya çıkan bu hatala-

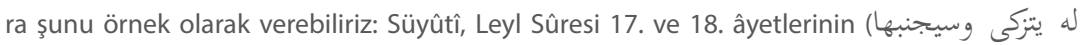
لالاتقى الذي يؤتي ما Hz Ebu Bekir'e has olduğunu ve bunun aksini söylemenin vehim içinde olduğunu iddia etmektedir. bu âyetler özelde $\mathrm{Hz}$ Ebu Bekir sebebiyle inmiş olabilir ancak bu âyetler söz konusu niteliklere sahip olan diğer müminleri de kapsamaktadır. Bu sebeple Kur'ân, vahye muhatap olan herkesin bu örneklerden esinlenerek hayatlarını dizayn etmelerini tavsiye etmektedir. Bkz: Süyûtî, el-Ittkân fî Ulûmi'I-Kur'ân, (Beyrut: Dâru'I-Kitâbi'I-Arabî, 2010), 88. 
Kavâidü't-Tefsir'in doğuşu ve günümüze kadarki gelişim sürecini inceleyip ilgili tarif ve tasnifleri göz önünde bulundurduktan sonra yapacağımız tarif sonuç olarak şu şekildedir:

'Kur'ân'ın anlaşılmasına yardımcı olan dil (Sarf, Nahiv ve Belâğat) ve mantık temelli kısa, öz ve kapsayıcı kurallar bütünüdür.'

Kavâidü't-Tefsir; Ulûmu'l-Kur'ân bilgileri eşliğinde Kur'ân'ı yorumlama faaliyetine girişen müfessirin - es-Sebt'in de vurguladığı gibi - keyfî yorumlara dalmasına engel olduğu gibi sahih bir anlayışla murâd-ı ilahiyi kavramasına da yardımcı olur.

\section{Tefsir Usûlü, Ulûmu'I-Kur'ân Ve Kavâidü't-Tefsir Kavramları Arasındaki İrtibat}

Tefsir Usûlü, Ulûmu'l-Kur'ân ve Kavâidü't-Tefsîr terimlerinin anlam analizini yaptıktan sonra bu kavramların birbirleri ile olan anlam ilişkisi üzerinde durmamız gerekmektedir. Çünkü zaman zaman Ulûmu'l-Kur'ân kavramı ile Tefsir Usûlü'nün, Tefsir Usûlü kavramı ile de Ulûmu'I-Kur'ân'ın kastedildiğini görmekteyiz. Bu iki kavramın birbiri yerine kullanılmasından kaynaklanan problemin yanında Kavâidü't-Tefsîr'in konumu ayrı bir önem arz etmektedir.

Tefsir Usûlü ve Ulûmu'I-Kur'ân kavramlarının birbiri yerine kullanılmasının ${ }^{100}$ yanı sıra birinin cüz/has diğerinin küll/âmm anlamıyla kullanıldığına da şahit olmaktayız. ${ }^{101}$ Bu iki kavrama Kavâidü't-Tefsir kavramının da eklenmesiyle konuyla ilgili bu üç kavramın mâhiyet ve içerikleri daha da karmaşık hale gelmektedir. Bununla birlikte bu kavramların tariflerinin de yeterli olmadığı ve mahiyetleri hakkında aktarılan bilgilerin bazen müphem bazen de karmaşık olduğu göze çarpmaktadır. Bu sebeple burada bizim problem olarak gördüğümüz husus, ilk olarak Kur'ân'ı yorumlama faaliyetine yönelik kullanılan bu üç kavramın birbirleri ile olan anlam ve içerik ilişkisinin ne olduğunu ortaya koymaktır.

100 Mennâu'l-Kattân, Mebâhis fî Ulûmi'l-Kur'ân, 16; Hidayet Zertürk, Ulûmu'l-Kur'ân ve Tefsir Usûlü, (İstanbul: Ravza Yayınları, 2012), 2, 138; Recep Orhan Özel, Keşşaf Tefsiri'nin Kur'an Illimleri Yönünden Incelenmesi, (Doktora Tezi, Ondokuzmayıs Üniversitesi, 2012), 13.

101 Ulûmu'l-Kur'ân'ın Tefsir Usûlü'nü kapsadığını dile getiren ilim adamlar ve eserleri için bkz; Fehd er-Rumî, Buhûs fî Usûli't-Tefsîr ve Menâhicuhû, (Riyad: Mektebetü't-Tevbe, 1996), 12; Zafer Koç, Kur'an Tefsirinde Yöntem Arayışları, (Doktora Tezi, Ankara Üniversitesi, 2007), 221; Harun Bekiroğlu, Tefsir Metodolojisi Açısından el-Burhân ve El-itkan, (Ankara: Araştırma Yayınları, 2013), 53; Halil Çiçek, 20. Asırda Kur'an Illimleri Çalışmaları (İstanbul: Timaş Yayınları, 1996), 27; Abdurrahman Çetin, Kur'ân İlimleri ve Kur'ân-ı Kerim Tarihi, (İstanbul: Dergâh Yayınları, 2014), 205; es-Sebt ise Usûlü't-Tefsir kavramı yerine Kavâid kavramını kullanır ve onu Ulûmu'l-Kur'ân'ın alt başlığı yani cüz'ü olarak görür. Bkz: Halid b. Osman es-Sebt, Kavâidü't-Tefsîr, 33. 
Bu üç kavramla ilgili yazılan eserlere baktığımızda bu eserlerin içeriklerinin ne olması gerektiği net bir şekilde belirlenmemiştir. Ulûmu'l-Kur'ân başlıklı eserlerde bazen Kavâid konularının, Kavâidü't-Tefsir başılıklı eserlerde ise bazen Ulûmu'l-Kur'ân konularının işlenmesi konumuzla ilgili ana problemlerdendir.

Bu kavramlarla ilgili çalışmalarda yapılan tariflerde cüz/küll ayrımı yapılırken hangisinin küll hangisinin cüz olduğu hakkında da somut veriler ya da mantıksal açıklamalar yapılmamıştır. Ayrıca bu kavramlar arasında anlam olarak ayrım yapan müellifler, tasniflerini bir delile dayandırmadan yalnızca kendi görüşlerini esas alarak aktarmışlardır.

Özellikle son dönemde dikkat çeken konulardan olan bu kavramların; içerikleri, mâhiyetlerindeki ayrım ve ortak noktaları bakımından tarifleri yapıımıştır. Kavramlar arasındaki farklara en çok atıf yapan müelliflerin, Türk ve Suudî âlimler olduğu da dikkat çekmektedir.

Usûlü't-Tefsir müellifi Rûmî'ye göre Tefsir Usûlü cüz, Ulûmu'l-Kur'ân ise küll'dür. Tefsir Usûlü'nün bazen Ulûmu'I-Kur'ân kavramı yerine kullanılmasını da Rûmî, belağattaki cüz'ü (parçayı) söyleyerek küll'ün (bütünün) kastedilmesi anlamında ele almaktadır. Rûmî, bu şekildeki kullanımı 'cüz'ün küll karşısındaki önemini ve değerini ortaya koymak' olarak açıklamaktadır. ${ }^{102}$ Bu sebeple o, Ulûmu'l-Kur'ân'ı üst, Tefsir Usûlü'nü ise onun alt başlığı olarak kabul etmektedir.

Abdurrahman el-Akk'ın eserinde Tefsir Usûlü ve Ulûmu'I-Kur'ân kavramlarını ayrı başlıklar altında ele alarak tariflerini yapması, onun bu kavramları anlam ve içerik bakımından farklı kabul ettiğinin delilidir. Tefsir Usûlü’nü 'kâide ve yöntem bakımından tefsire yaklaşım' olarak kabul eden müellif, bu kavramı'Kur'ân'ı tefsir edebilmek' olarak açıklar. Müellif bu açıklamasıyla, aklî melekeleri kullanarak Kur'ân'ı yorumlamadaki yöntemsel yaklaşımları ifade etmektedir. Ulûmu'I-Kur'ân'ın ise 'hangi bakımdan olursa olsun Kur'ân hakkında bilgi veren ilimler'i kapsadığını söylemektedir. ${ }^{103}$ el-Akk, yaptığı bu tariflerle iki kavram arasındaki fark, içerik ve mahiyetleri bakımından birbirinden ayıran müelliflerden sayılmaktadır.

Nureddin Itr ve Muhyiddin Biltâcî da konu hakkında görüş bildiren diğer müelliflerdendir. Onlara göre Tefsir Usûlü; 'Tefsir Tarihi bilgilerini kapsayan ve müfessirlerin metotlarını, Tefsir kaynaklarının farklıı̆ını etkileyen faktörleri inceleyen 
bir ilimdir'.104 Daha çok naklî yönü ağır basan bilgiler manzumesi şeklinde tarif ettikleri Tefsir Usûlü anlayışında el-Akk'tan ayrılmaktadırlar.

Müsâid b. Süleyman ise Tefsir Usûlü ile Ulûmu'l-Kur'ân arasındaki ilgi bağını şu şekilde açıklamaktadır: 'Tefsir Usûlü; Tefsir ilminde derinleşmek isteyen kimselerin ihtiyaç duyduğu öncelikli bilimsel ilkelerdir. Bu ilkeler 'Ilmü't-Tefsir'in bir cüzüdür. 'Illmü't-Tefsir ise Ulûmu'l-Kur'ân'ın cüzüdür. Sonuç olarak Usûlü't-Tefsir'e ait bütün bilgi birikimi Ulûmu'l-Kur'ân'dır. Ancak Ulûmu'I-Kur'ân'a ait bütün bilgi birikimi Tefsir Usûlü değildir. ${ }^{105}$ Müsâid b. Süleyman bu açıklamalarıyla Tefsir Usûlü'nü Ulûmu'l-Kur'ân'ın cüz'ünün cüz'ü mesabesine indirmiş; Tefsir Usûlü’nün anlam aralığını daraltmış ve Tefsir Usûlü için iddia ettiği ilkeler konusunda net bilgiler vermemiştir. Ülkemizde Müsâid b. Süleyman ile neredeyse aynı görüşte olan Ömer Çelik'e göre de Tefsir Usûlü özel, Ulûmu'l-Kur'ân ise daha üst ve genel bir anlam ifade etmektedir. ${ }^{106}$ Bununla birlikte Çelik, Tefsir Usûlü kavramının anlam ve kapsamına uygun bir biçimde ülkemizde karşılık bulamadığını ve genellikle Ulûmu'l-Kur'ân bağlamında ele alınan eserlerin Tefsir Usûlü başlığıyla sunulduğunu ifade etmektedir. ${ }^{107}$

Müsâid b. Süleyman, İbn Useymin'in yazdığı Şerhu Usûlin fi't-Tefsir ${ }^{108}$ adlı eseri eleştirerek bu eserin Tefsir Usûlü değil Ulûmu'l-Kur'ân yönü ağır basan bir eser olduğunu dile getirmiştir. Bununla birlikte Müsâid b. Süleyman Tefsir Usûlü'nü; nazarî bilgiler, tefsir etmenin yolları-kaynakları ve tefsirde ihtilaflar olmak üzere

104 Nurettin Itr, Muhâdaratün fî Ulûmi'l-Kur'ân, (Şam: Dâru'I-Fikr, 1987), 135; Muhyiddin Biltâcî, Dirâsetün fi't-Tefsîr ve Usûlihî, (Beyrut: yayınevi yok, 1987), 5.

105 Müsâid b. Süleyman et-Tayyâr'a ait olan bu görüşü yayımlanan basııı eserlerinde bulamadık. Ancak bu görüşünü; kendisine sorulan bir soru üzerine verdiği yazılı bir cevap olduğunu, makale formatında kaleme aldığını internet verilerinden elde ettik. Metin aynı zamanda pdf formatında erişime açıktır. Bununla birlikte Müsâid b. Süleyman, bu kadar net ve açık olmasa da bu konudaki bazı görüşlerine el-Muharraru fi Ulûmi'l-Kur'ân adlı eserinde az da olsa değinmiştir. Bkz: Müsâid b. Süleyman et-Tayyâr, el-Muharraru fi Ulûmi'l-Kur'ân, (Cidde: Merkezü'd-Dirâset ve'l-Malûmati'l-Kur'âniyye, 2008), 52-53; erişim: 15.12.2019, https://www.attyyar.net/uploads/1315692334.pdf; erişim: 15.12.2019, https://vb.tafsir.net/tafsir1060/\#.XfZegugzZPY

106 Ömer Çelik, 'Hicrî V-XI Asırlarda Kur'ân İlimleri', 52-53; Erdoğan Baş da aynı aynı kanaati taşımaktadır. Bkz: Erdoğan Baş, 'Kur'ân İlimlerinin Doğuşu ve Tarihi Gelişimi (I-VI Asır)', 23-24.

107 Ömer Çelik, 'Hicrî V-XI Asırlarda Kur'ân Illimleri', 52-53.

108 Müsaid b. Süleyman'ın eleştirdiği Muhammed b. Salih el-Useymin'e ait olan Şerhu Usûlin fi't-Tefsir adlı kitap; Kur'ân Tarihi, Tefsir Tarihi ve bazı Ulûmu'I-Kur'ân konularını içeren bir eserdir. Bununla birlikte eserde Usûlü't-Tefsir ile Ulûmu'I-Kur'ân'ın ayrımına dair herhangi bir görüş de dile getirilmemiştir. Bununla birlikte Muhammed b. Salih el-Useymin'e ait Şerhu Mukaddimeti't-Tefsir adlı bir eser daha vardır. Müellif bu eserini İbn Teymiyye'ye ait olan Mukaddime fi Usûli't-Tefsir'e şerh olarak kaleme almıştır. 
üç kısma ayırmanın gerekliliğini de dile getirmektedir. ${ }^{109}$ Müsâid b. Süleyman, İbn Useymin'e yönelttiği eleştirilerde haklılık payı olsa da Tefsir Usûlü için yaptığı tasnifte Tefsir Tarihi ve İhtilâfü'l-Müfessirîn bağlamında ele alınacak konuları farkIı şekilde ele alması sebebiyle içerik ve anlam karışıklığına yol açmıştır.

Bizim burada dikkat çekmek istediğimiz bir başka konu, Ulûmu'I-Kur'ân'ın küll/ amm olarak kabul edilip kavram üzerine yapılan tariflerin bu kabullerle örtüşmemesidir. Çünkü Tefsir Usûlü kavramını tarif ederken bazı müellifler onu cüz/ fer'/hâs kabul etmekte ve tarifini 'Kur'ân yorumunda takip edilecek yöntem ve prensipler' olarak yapmaktadırlar. ${ }^{110}$ Ancak şu unutulmamalıdır ki tefsir faaliyetine girişen kişi için Kur'ân yorumunda takip edilecek metot/yöntem ve prensiplerden önce, bu yöntem için gerekli olan bilgi birikiminin elde edilmesi gerekmektedir. Bu da Ulûmu'l-Kur'ân ve Kavâidü't-Tefsir bilgisiyle olur. Dolayısıyla Ulûmu'l-Kur'ân ve Kavâidü't-Tefsir'e dair ilmî birikimini elde etmeden usûlî bir bakış açısıyla Kur'ân'ı yorumlamaya çalışmak uygun bir tavır değildir. Bu sebeple biz Tefsir Usûlü kavramını küll/âmm/asl olarak, Ulûmu'l-Kur'ân ve Kavâidü't-Tefsir kavramlarını ise cüz/hâs/fer' olarak kabul ediyoruz. Çünkü Kur'ân yorumunda usûlî yöntem takip edilecekse - ki biz buna Tefsir Usûlü diyoruz - öncelikle bilinmesi gereken ilimler öğrenilmeli; yöntem ise bunun üzerine belirlenmelidir.

Tefsir Usûlü ve Ulûmu'I-Kur'ân kavramları arasındaki anlam ve içerik farkını ortaya koymaya çalışan ilim adamları Kavâidü't-Tefsir'i dikkate almadan yaptıkları tariflerde bazı anlam karmaşasına sebep olmaktadır. Ulûmu'I-Kur'ân'ın; Kur'ân ve Tefsir ile ilgili tüm ilim dallarını kapsadığını ifade eden Salih Gedük, Tefsir Usûlü'nün tarifini ise 'izâh, kâide ve kurallar bütünü' şeklinde yapmaktadır."11 Ancak burada şu ayrımı yapmamız gerekmektedir: Arap dili üzerindeki mantık merkezli kural ve kâideleri, Kavâidü't-Tefsir olarak kabul etmekteyiz. Zira bu kurallar her ne kadar usûlî bir yaklaşımı ortaya koyarken kullanılan öğeler olsa da Kavâidü't-Tefsir'in konusudur.

Ülkemizde Tefsir Usûlü ve Ulûmu'l-Kur'ân kavramları arasındaki farkı ortaya koyan en kapsamlı çalışma, Ali Turgut'a ait olan Tefsir Usûlü ve Kaynakları adlı

109 Me'l-Fark beyne Ulûmi'I-Kur'ân ve Usûlü't-Tefsir', erişim: 15.12.2019, https://vb.tafsir.net/tafsir1060/\#.XfZegugzZPY

110 Ömer Çelik, "Hicrî V-XI Asırlarda Kur'ân İlimleri", 51-52; Erdoğan Baş, 'Kur'ân Illimlerinin Doğuşu ve Tarihi Gelişimi (I-VI Asır)', 23-24

111 Salih Gedük, 'Ulûmu'I-Kur'ân, Usûlü't-Tefsir Kavramları ve Tefsirde Usûlün İmkânı Meselesi', Erciyes Üniversitesi Sosyal Bilimler Enstitüsü Dergisi, 39 (2015): 212-213. 
eserdir. Turgut, bu iki kavram arasındaki farkı, kavramların ortaya çıktığı tarihleri de göz önünde bulundurarak yedi maddede özetlemiş ancak yaptığı bu tasnifle kavramlar arasındaki anlam ve kullanım farklarını daha da anlaşılmaz hale getirmiştir. Tefsir Usûlü'nün karşılığı olarak (konulu Kur'ân ilimlerini hariç) kapsamlı ve müstakil bir biçimde ortaya konulmuş Ulûmu'l-Kur'ân çalışmalarını gösteren Turgut, günümüzde bu iki kavramın ortak karşılığı olarak 'Tefsir Metodolojisi' kavramını öne sürmektedir. ${ }^{112}$

Yukarıda saydığımız kavramlar arası anlam karışıklığından oluşan problemler dolayısıyla ıstılâhî anlam gelişimini tamamlayamamış ${ }^{113}$ olan Tefsir Usûlü'ne yönelik yapılan eleştirileri de kabul etmemiz mümkün değildir. Bununla birlikte Ulûmu'l-Kur'ân kavramının Tefsir Usûlü ilminin epistemolojik yönünü; Kavâidü't-Tefsir kavramının ise bu ilmin metodolojik yönünü ifade ettiğini düşünüyoruz.

Epistemolojide bir bilginin kabulüne dair hakikatler; olgusal, aşkın ve pragmatik olmak üzere üç farklı kategoride ele alınmaktadır. ${ }^{114}$ Olgusal ve aşkın hakikat mutlak bir doğru olarak kabul edilirken pragmatik hakikat ise izâfidir. Buna göre Ulûmu'l-Kur'ân epistemolojik açıdan bilgilerin olgusal ve aşkın yönünü; Kur'ân'ın yorumu/tefsiri açısından pragmatik yönünü ifade eder. Buna örnek olarak Ulûmu'l-Kur'ân ve Tefsir Usûlü başlığıyla yazılan eserlerde işlenen İhtilâfü'l-Müfessirîn konusunu gösterebiliriz. İhtilâfü'l-Müfessirîn, müfessirlerin âyetlerin yorumlarında ulaştıkları farklı sonuçları bizlere ihtilaf bağlamında sunmaktadır. Ancak unutulmamalıdır ki bunun temelinde müfessirlerin başlangıçta ön kabulü olan olgusal ve aşkın bilgilerin (Ulûmu'l-Kur'ân) içinden ulaştıkları farklı yorumlar, pragmatik bilgi olarak subjektif bir şekilde ortaya çıkmaktadır. Bu da bize Kur'ân'ın anlam genişliğini, her döneme ve her bireye ayrı ayrı hitap ettiğini göstermektedir.

Bununla birlikte bu alanda yapılmış akademik çalışmaları incelediğimizde hemen hemen hepsinin bir isim ya da eser bazında '...'nın Tefsir Usûlü Açısından İncelenmesi' başlığıyla ele alındığını görmekteyiz. Bu konuda yapılan her bir çalışma; başındaki problemin tespiti ve sonucunun farklılığı sebebiyle alanında

112 Ali Turgut, Tefsir Usûlü ve Kaynakları, (İstanbul: Marmara Üniversitesi IIlahiyat Fakültesi Vakfı Yayınları, 1991), 5.

113 Halis Albayrak, Tefsir Usûlü (Yöntem - Ana Konular - Illkeler - Teklifler), (ìstanbul: Şule Yayınları, 2016), 12.

114 Hakikatlerin tasnifi için bkz: Alparslan Açıkgenç, Bilgi Felsefesi, (İstanbul: İnsan Yayınları, 2016), 121-129. 
tekrar etmemektedir. Bu sebeple usûlî bakış açısı ile müelliflerin eserlerinde ulaştıkları yorumların öznelliği, onların keyfî bir yorumla eser telif ettikleri anlamına gelmemektedir.

Bizim burada savunduğumuz; Tefsir Usûlü'nün salt öznel/subjektif bir yapıda bulunduğu ve Kur'ân tefsirinde delilsiz ve bilgisiz bir şekilde yorum yapmaya yol açtığı değil Ulûmu'l-Kur'ân ve Kavâidü't-Tefsir altyapısıyla desteklenmiş bir bireyin metne, lafzın müsaadesi oranında sübjektifliğini yansıtabilmesidir. Bu da genellikle Ulûmu'I-Kur'ân ve Kavâidü't-Tefsir özelinde sunulan bilgilerin içerisinde belli tercihlerle ortaya çıkmaktadır. Nesh meselesini buna delil olarak gösterebiliriz. Nesh'in varlığı ya da yokluğu Ulûmu'l-Kur'ân'a dair konular içerisinde tartışılmış ve sonucu neredeyse ittifakı mümkün olmayan bir hal almıştır. İşte bu noktada ittifakın olmayışı ve Tefsir Usûlü'nün mutlak yargıya ulaştırmaması nedeniyle Tefsir Usûlü'nün olmadığını iddia etmek, aklın ve insan olgusunun varlığını inkâr etmektir.

Netice itibariyle burada şunu diyebiliriz:

Ulûmu'l-Kur'ân müfessire, Kur'ân'ı yorumlama faaliyetine girişmeden önce ön bilgiler sunar. Müfessir, bu bilgiler içerisinden tercihlerde bulunur ve Kavâidü't-Tefsir eşliğinde Kur'ân'ı yorumlama faaliyetine girişir. Lafzın delâletine dair anlam aralığını yakalamaya çalışan müfessir, bir yoruma/tefsire ulaşır. Bu durum, kısmen öznel olmakla birlikte Tefsir Usûlü'nün kendisidir. Diğer bir ifadeyle Tefsir Usûlü; 'Ulûmu'l-Kur'ân'ın sunduğu ön bilgilerle Kavâidü't-Tefsir rehberliğinde Kur'ân'ı yorumlamada yöntemi/metodudur.' Ayrıca müfessirin; Kur'ân metnine yaklaşırken, kendisine sunulan bilgilerden tercihte bulunması ve lafzın delâletine dair anlam aralığını yakalamak için kâideleri metne uygulama biçimi de müfessirin usûlünü ortaya koymaktadır.

\section{Sonuç}

Kur'ân'ı anlamaya dair yazılan eserler; Tefsir Usûlü, Ulûmu'l-Kur'ân ve Kavâidü't-Tefsir başıاıkları ile yayımlanmıştır. Ulûmu'l-Kur'ân kavramı ile başlayan bu sürece daha sonra Kavâidü't-Tefsir ve Tefsir Usûlü kavramları eklenmiştir. Son döneme gelindiğinde ise üst başlık olarak Tefsir Usûlü kabul edilmiş ve eserler bu minvalde kaleme alınmıştır. Eserlerine bu başlıkları koyan müellifler, bu kavramların içerik ve anlamsal çerçevesine dair farklı görüşler ortaya koymuşlardır. Bu da son dönemde Tefsir ilminde kavramsal birlikteliğin olmadığı gerçeğini ortaya çıkarmıştır. 
Tefsir ilmine; kendisinden beklenen teknik bir metot sunmaması ve her tefsirde farklı yorumların bulunması gerekçesiyle bir usûlünün olmadığı eleştirisi yöneltilmiş; bu da Tefsir Usûlü'nün mâhiyeti problemini doğurmuştur. Aslında bu problemin temelinde, usûl kelimesinin anlamında teknik bir yön iddiası olması ve bunun uygulama alanında karşılık bulamaması yatmaktadır. Bununla birlikte Fıkıh Usûlü gibi kullanımlar sebebiyle usûl kelimesinden beklentinin faklı bir alana kayması söz konusu olmuştur.

Kur'ân'a muhatap olan, onu anlamak isteyen ve bu doğrultuda çaba sarf eden kimsenin Tefsir Usûlü'nden sistematik/teknik bir beklentiye girmesi doğaldır. Nitekim son döneme kadar yazılan eserler arasında bu konunun kavramsal çerçevesi net belirlenememiş; mâhiyetine ilişkin açıklamalar yeterince yapılmamıştır. Bu sebeple Tefsir Usûlü'nün mahiyetinin ortaya konulması ve neticede beklentinin buna göre şekillenmesi gerekmektedir.

Bu amaçla, alanda yazılmış eserler genelinde yaptığımız çalışmayla şu neticeye ulaşmış bulunmaktayız: Tefsir Usûlü'nde Ulûmu'l-Kur'ân kavramı bu ilmin epistemolojik yönünü; Kavâidü't-Tefsir kavramı ise metodolojik yönünü ortaya koymaktadır. "Ulûmu'l-Kur'ân + Kavâidü't-Tefsir = Tefsir Usûlü” olarak formüle ettiğimiz bu yaklaşımda üst kavram Tefsir Usûlü'dür. Murâd-ı ilâhinin anlaşılması için dil, tarih ve Kur'ân İlimleri'nden istifade edilmesini vurgulayan Zerkeşî́nin, yaptığımız bu formüle işaret ettiği söylenebilir.

Sonuç olarak Tefsir, bir ilimdir ve usûlü de Ulûmu'l-Kur'ân ve Kavâidü't-Tefsir kavramları ile inşa edilmektedir. Ortaya koyduğumuz bu Tefsir Usûlü anlayışı, mutlak bir iddia olmamakla birlikte bu ilmin gelişimine dair en kapsamlı tekliftir.

\section{Kaynakça}

Abdulhamit, Muhsin, Dirâsât fí Usûli Tefsiri'l-Kur'ân, Mağrib: Dâru's-Sakâfe, 1984.

Açıkgenç, Alparslan, Bilgi Felsefesi, İstanbul: İnsan Yayınları, 2016.

Albayrak, Halis, Tefsir Usûlü (Yöntem - Ana Konular - IIlkeler - Teklifler), İstanbul: Şule Yayınları, 2016.

Ali Haydar Efendi, Usûl-i Fıkıh Dersleri, İstanbul: Üçdal Neşriyat, 1966.

Arslan, Gıyasettin, 'Tefsir Usûlü'ne Fıkıh Usûlü Karıştırmak', Fırat Üniversitesi Illahiyat Fakültesi Dergisi, 13/2 (2008): 1-34.

Baş, Erdoğan, 'Kur'ân İlimlerinin Doğuşu ve Tarihi Gelişimi (I-VI Asır)', Kur'ân ve Tefsir Araştırmları-III, İstanbul: Ensar Yayınları, 2002, 21-42.

Bekiroğlu, Harun, Tefsir Metodolojisi Açısından el-Burhân ve El-itkan, Ankara: Araştırma Yayınları, 2013. Biltâcî, Muhyiddin, Dirâsetün fi't-Tefsîr ve Usûlihî, Beyrut: yayınevi yok, 1987. 


\section{MîZÂNƯ̈'L-HAK}

Cerrahoğlu, İsmail, Tefsir Usûlü, Ankara: Türkiye Diyanet Vakfı Yayınları, 2008.

Cüceloğlu, Doğan, Yeniden İnsan Insana, İstanbul: Remzi Yayınevi, 2000.

Cürcânî, Ali b. Muhammed b. Ali, et-Ta'riffât, Dâru'd-Diyane li't-Türâs, Tsz.

Çağbayır, Yaşar, Ötüken Türkçe Sözlük, İstanbul: Ötüken Yayınları, 2007.

Çalışkan, İsmail, Tefsir Usûlü, Ankara: Ankara Okulu Yayınları, 2017.

Çetin, Abdurrahman, Kur'ân Illimleri ve Kur'ân-ı Kerim Tarihi, İstanbul: Dergâh Yayınları, 2014.

Çiçek, Halil, 20. Asırda Kur'an Illimleri Çalışmaları, İstanbul: Timaş Yayınları, 1996.

Deliser, Bilal, Kur'an Ilimleri ve Tefsir Usûlü, İstanbul: Rağbet Yayınları, 2014.

Demir, Şehmus, Kur'ân'ın Yeniden Yorumlanması, İstanbul: İnsan Yayınları, 2018.

Demirci, Mehmet, "Kurtubî'nin El-Cami' li Ahkâmi'I-Kur'ân Adlı Eserinin Tefsir Usûlü Açısından Değerlendirilmesi", Doktora Tezi, Erciyes Üniversitesi, 2009.

Demirci, Muhsin, Tefsir Usûlü, İstanbul: Marmara Üniversitesi Illahiyat Fakültesi Vakfı Yayınları, 2016.

Demirci, Muhsin, Tefsir Terimleri Sözlüğü, İstanbul: IFAV Yayınları, 2015.

Develioğlu, Ferit, Osmanlıca-Türkçe Ansiklopedik Lûgat, Ankara: Aydın Yayınları, 2011.

Dumlu, Ömer, Tefsir Usûlü, İzmir: Tibyan Yayıncılık, 2017.

Ebu's-Suud, b. Muhammed el-Imâdî el-Hanefî, İrşâdü'I-Aklı's-Selîm ilâ Mezâye'I-Kitâbi'I-Kerîm, Riyad: Mektebetü'r-Riyad el-Hadîse, Tsz.

ed-Dihlevî, Şah Veliyyullah, el-Fevzü'l-Kebîr fî Usûli't-Tefsîr, İstanbul: I'tisam Yayınları, 2015.

el-Akk, Halid Abdurrahman, Usûlü't-Tefsîr ve Kavâiduhû, Beyrut: Dâru'n-Nefâis, 2007.

el-Askerî, Ebû Hilal, el-Furûku'I-Lüğaviyye, Kahire: Dâru'I-IIm ve's-Sekâfe, 1997.

el-Beğavî, Ebû Muhammed Hüseyin b. Mesud, Meâlimü't-Tenzîl, Kahire: ed-Dâru'l-Âlemiyye, 2015.

el-Beydavî, Abdullah b. Ömer b. Muhammed, Envâru't-Tenzîl ve Esrâru't-Te'vill, Beyrut: Dâr-u îhyâi't-Türâsi'l-Arabî, Tsz.

el-Cessâs, Ebu Bekr Muhammed b. Ali, Ahkâmü'I-Kur'ân, Beyrut: Dâr-u Ihyâi't-Türâsi'l-Arabî, 1992.

el-Cevheri, İsmail b. Hammad, es-Sıhah Tacu'I-Luğa ve Sıhahı'I-Arabiyye, Beyrut: Dâru'I-IImi li'I-Melâyîn, 1990.

el-Ezheri, Ebu Mansur Muhammed b. Ahmed, Tehzibü'l-Luğa, Kahire: ed-Daru'l-Mısriyye li't-Te'lif ve't-Terceme, Tsz.

el-Ferâhidî, Halil b. Ahmed Kitabü'l-Ayn, Beyrut: Dâr-u Ihyâai't-Türâsi'l-Arabî, 2005.

el-Gazzâlî, Muhammed b. Muhammed, el-Mustasfâ min 'Ilmi'I-Usûl, Medine: yayınevi yok, Tsz.

el-Hûlî, Emîn, Menâhicu Tecdîdi fi'n-Nahv ve'I-Belâğa ve't-Tefsîr ve'l-Edeb, Beyrut: Dâru'I-Marife, 1971.

el-Hüseynî, Halil b. İbrahim, ed-Dürru'n-Nesîr fi Usûli't-Tefsîr, Kahire: Dâru'r-Risâle, 1993.

el-Isfahânî, Râgıb, el-Müfredât, Dimeşk: Dâru'I-Kalem, 2014.

el-Kurtubî, Ebû Abdillah Muhammed b. Ahmed b. Ebî Bekr, el-Câmi' li Ahkâmi'l-Kur'ân, Beyrut: Müessesetü'r-Risâle, 2006.

el-Merağî, Ahmed Mustafa, Tefsîru'l-Merağî, Kahire: Mustafa el-Bâbî el-Halebî, 1946.

el-Mes'ûdî, Ebi'I-Hasen Ali b. Hüseyin b Ali, Mürûcu'z-Zeheb ve Meâdini'I-Cevher, Beyrut: el-Mektebetü'l-Asriyye, 2005.

el-Müberred, Muhammed b. Yezîd b. Abdilekber b. Umeyr, el-Kâmil fi'l-Edeb, Beyrut: Müessese- 
türr-Risâle, 1986.

el-Useymin, Muhammed b. Salih, Şerhu Usûlin fi't-Tefsir, Riyad: Müessesetü Şeyh Muhammed b. Salih el-Useymin el-Hayriyye, h.1434.

Emiroğlu, İbrahim, Klasik Mantığa Giriş, Ankara: Elis Yayınları, 2016.

er-Rûmî, Fehd b. Süleyman, Buhûs fi Usûli't-Tefsîr ve Menâhicuhû, Riyad: Mektebetü't-Tevbe, 1996.

er-Rûmî, Fehd, Buhûs fî Usûli't-Tefsîr ve Menâhicuhû, Riyad: Mektebetü't-Tevbe, 1996.

es-Sabbâğ, Muhammed b. Lütfi, Buhûsün fi Usûli't-Tefsir, Beyrut: Mektebetü'l-İslâmî, 1988.

es-Sâbûnî, Muhammed Ali, et-Tibyân fí Ulûmi'l-Kur'ân, İstanbul: Mektebetü's-Sirâc, Tsz.

es-Sebt, Halid b. Osman, Kavâidü't-Tefsîr, Kahire: Dâru İbnu Affân, 2001.

eş-Şûm, Muhammed Kâsım, Ulûmu'I-Kur'ân ve Menâhicü'l-Müfessirîn, Beyrut: Dâru'I-Kütibi'I-IIImiyye, 2014.

et-Tayyâr, Müsâid b. Süleyman, el-Muharraru fi Ulûmi'I-Kur'ân, Cidde: Merkezü'd-Dirâset ve'I-Malûmati'l-Kur'âniyye, 2008.

et-Tayyâr, Müsâid b. Süleyman, et-Tahrîr fî Usûli't-Tefsîr, Cidde: Merkezü'd-Dirâseti ve'I-Ma'lûmeti'I-Kuraniyye, 2014.

et-Tayyâr, Müsâid b. Süleyman, Füsûlün fî Usûli't-Tefsîr, Riyad: Dâru'n-Neşri'd-Düvelî, 1993.

et-Teftâzânî, Tehzibu'I-Mantık ve'I-Kelam, Mısır: Matbaatü's-Saade, 1912.

Eyüpoğlu, Osman, Murat Yıldız, 'Kur'ân'ı Anlamaya Yönelik Literal ve Kültürel Yaklaşımların sosyal Değişmeye Uyum Açısından İşlevselliği', Manas Sosyal Araştırmalar Dergisi, 5/3 (2016): 163-198.

ez-Zebîdî, Seyyid Muhammed Murtazâ el-Hüseynî, Tâcu'I-Arûs min Cevâhiri'l-Kâmûs, Kuveyt: Matbaat-u Hükûmet-i Kuveyt, 1974.

ez-Zemahşerî, Ebu'I-Kasım Mahmud b. Ömer, el-Keşşâf an Hakâiki't-Tenzîl ve Uyûni'l-Ekâvîl fî Vücûhi't-Te'vîl, Beyrut: Dâr-u İbn Hazm, 2012.

ez-Zeynü'l-Mekkî, İsmail b. Osman, el-Kavlü'I-Münîr fí 'Ilmi Usûli't-Tefsir, Riyad: el-Maârifü'l-Kur'âniyye, 2007.

ez-Zürkânî, Muhammed Abdülazîm, Menâhilü'I-Irfân fî Ulûmi'I-Kur'ân, Beyrut: Dâru'I-Kütübi'I-IIImiyye, 2013.

Fığlalı, Ethem Ruhi,'Hâricîler', (İstanbul: Diyanet Vakfı Yayınları, 1997), XVI, 169-175.

Gedük, Salih, 'Ulûmu'I-Kur'ân, Usûlü't-Tefsir Kavramları ve Tefsirde Usûlün İmkânı Meselesi', Erciyes Üniversitesi Sosyal Bilimler Enstitüsü Dergisi, 39 (2015): 207-221.

Görener, İbrahim, 'Algılama - Anlama ve Tefsir', Dokuz Eylül Üniversitesi Ilahiyat Fakültesi Dergisi, 17 (2003): 275-304.

Görener, Ibrahim, Tefsir ve Tefsir Usûlü Üzerine Düşünceler, Kayseri: Laçin Yayınları, 2004.

Itr, Nurettin, Muhâdaratün fi Ulûmi'I-Kur'ân, Şam: Dâru'I-Fikr, 1987.

İbn Arafe, Ebû Abdillah Muhammed et-Tunusî, Tefsîr-u ibn Arafe, Beyrut: Dâru'I-Kütübi'I-Ilmiyye, 2008. İbn Âşûr, Muhammed Tâhir, et-Tahrîr ve't-Tenvîr, Tunus: ed-Dâru't-Tunusiyye, 1984.

İbn Fâris, Ebu'I-Hüseyn Ahmed, Mu'cemu Mekâyîsü'l-Lüğa, Beyrut: Dâr-u Ihyâi't-Türâsi'l-Arabî, 2008.

İbn 'Imâd, Abdü'l-Hayy b. Ahmed el-Hanbelî, Şezerâtü'z-Zeheb fi Ahbâri men Zeheb, Beyrut: Dâr-u İbn Kesir, 1989.

İbn Manzûr, Ebu'l-Fadl Cemaleddin Muhammed b. Mükerrem, Lisânü'l-Arab, Beyrut: Dâr-u Sâdır, 1967. 


\section{MÎZÂNỬ'L-HAK}

İbn Teymiyye, Takıyyüddîn, Mukaddime fi Usûli't-Tefsîr, Beyrut: Dâr-u İbn Hazm, 2012.

Kâfiyeci, Kitâbû't-Teysîr fi Kavâidi 'Ilmi't-Tefsîr, Ankara: Ankara Üniversitesi Illahiyat Fakültesi Yayınları, 1974.

Kırbaşoğlu, Hayri, İslâmî Ilimlerde Metot Sorunu, Ankara: Otto Yayınları, 2015.

Kırca, Celal, "Müzakere", İslâmî Ilimlerde Metodoloji (Usûl) Meselesi-I, İstanbul: Ensar Yayınları, 2005, 622-625.

Koç, Zafer, Kur'an Tefsirinde Yöntem Arayışları, Doktora Tezi, Ankara Üniversitesi, 2007.

Kotan, Şevket, Kur'an, Yorum ve Tarih - Tarihselci Okumanın Çıkmazları, İstanbul: Hikav Yayınları, 2018.

M.Yaşar Kandemir, 'Ahmet b. Nasr el-Huzâi', DiA, II, 110, İstanbul: Diyanet Vakfı Yayınları, 1989.

Mehmet Görmez, Sünnet ve Hadisin Anlaşılması ve Yorumlanmasında Metodoloji Sorunu, Ankara: Türkiye Diyanet Vakfı Yayınları, 1997.

Mennâu'I-Kattân, el-Vecîz fî Usûli't-Tefsir, Riyad: Matbaatü's-Selefiyye, h.1379.

Mennâu'I-Kattân, Mebâhis fi Ulûmi'I-Kur'ân, Beyrut: Müessesetü'r-Risâle, 2015.

Muhaammed Ali et-Tehânevî, Keşşâf-u Istılâhâti'I-fünûn ve'I-Ulûm, Lübnan: Mektebet-ü Lübnan, 1996.

Muhammed Emin eş-Şinkıtî, Eḍâü'I-Beyân fi İ̇âhi'l-Kur 'ân bi'I-Ḳur'ân, Mekke: Dâr-u Âlemi'l-Fevâid, h.1426.

Muhâsibî, el-Akl ve Fehmü'l-Kur'ân, Dimeşk: Dâru'I-Fikr, 1971.

Ömer Çelik, 'Hicrî V-XI Asırlarda Kur'ân Illimleri', Kur'ân ve Tefsir Araştırmları-III, İstanbul: Ensar Yayınları, 2002.

Özel, Recep Orhan, Keşşaf Tefsiri'nin Kur'an Ilimleri Yönünden Incelenmesi, Doktora Tezi, Ondokuzmayıs Üniversitesi, 2012.

Paçacı, Mehmet, Kur'ân ve Ben Ne Kadar Tarihseliz, Ankara: Ankara Okulu Yayınları, 2016.

Polat, Fethi Ahmet, Çağdaş İslâm Düşüncesinde Kur'ân'a Yaklaşımlar, İstanbul: İz Yayınları, 2018.

Salih, Subhi, Mebâhis fî Ulûmi'I-Kur'ân, Şam: Matbaatu'I-Câmiatü's-Suriyye, 1958.

Sâmî, Şemseddin, Kâmûs-i Türkî, İstanbul: Ikdâm Matbaası, h.1317.

Süyûtî, el-Ittkân fî Ulûmi'l-Kur'ân, Beyrut: Dâru'I-Kitâbi'l-Arabî, 2010.

Süyûtî, Celaleddin Buğyetü'I-Vuât fi Tabakâti'I-Lugavîyyin ve'n-Nuhât, Beyrut: Dâru'I-Fikr, Tsz.

Şimşek, M. Sait, "Illahiyat Fakültelerinde Tefsir Dersi-Problemler ve Öneriler”, Tefsir Eğitim ve Öğretiminin Problemleri, Bursa: Kurav Yayınları, 2007.

Şimşek, M. Sait, "Müzakere", İslâmî llimlerde Metodoloji (Usûl) Meselesi-I, İstanbul: Ensar Yayınları, 2005, 628-630.

Talip Türcan, "Fıkıh Usûlü: Tanım Tarihçe ve Tedvin", Fıkıh Usûlü El Kitabı içinde, ed: Talip Türcan, Ankara: Grafiker, 2019.

Turgut, Ali, Tefsir Usûlü ve Kaynakları, İstanbul: Marmara Üniversitesi Ilahiyat Fakültesi Vakfı Yayınları, 1991.

Zarzur, Adnan Muhammed, Ulûmu'l-Kur'ân, Beyrut: el-Mektebetü'l-Islâmî, 2014.

Zertürk, Hidayet, Ulûmu'I-Kur'ân ve Tefsir Usûlü, İstanbul: Ravza Yayınları, 2012.

'Me'I-Fark beyne Ulûmi'I-Kur'ân ve Usûlü't-Tefsir' erişim: 15.12.2019, https://vb.tafsir.net/tafsir1060/\#. XfZegugzZPY 